\title{
Agronomic Efficiency of Animal-Derived Organic Fertilizers and Their Effects on Biology and Fertility of Soil: A Review
}

\author{
Shantanu Bhunia ${ }^{1}\left(\right.$, Ankita Bhowmik ${ }^{1}$, Rambilash Mallick ${ }^{2}$ and Joydeep Mukherjee ${ }^{1, *}$ \\ 1 School of Environmental Studies, Jadavpur University, Kolkata 700032, India; shanu.bhunia@gmail.com (S.B.); \\ ankitabh30@gmail.com (A.B.) \\ 2 Department of Agronomy, Institute of Agricultural Science, University of Calcutta, Kolkata 700019, India; \\ rbmallick@rediffmail.com \\ * Correspondence: joydeep.mukherjee@jadavpuruniversity.in; Tel.: +91-33-2414-6147; Fax: +91-33-2414-6414
}

check for

updates

Citation: Bhunia, S.; Bhowmik, A.; Mallick, R.; Mukherjee, J. Agronomic Efficiency of Animal-Derived Organic Fertilizers and Their Effects on Biology and Fertility of Soil: A Review. Agronomy 2021, 11, 823. https://doi.org/10.3390/ agronomy11050823

Academic Editors: Enrique Eymar and Carlos García-Delgado

Received: 25 March 2021

Accepted: 20 April 2021

Published: 22 April 2021

Publisher's Note: MDPI stays neutral with regard to jurisdictional claims in published maps and institutional affiliations.

Copyright: (c) 2021 by the authors. Licensee MDPI, Basel, Switzerland. This article is an open access article distributed under the terms and conditions of the Creative Commons Attribution (CC BY) license (https:// creativecommons.org/licenses/by/ $4.0 /)$.

\begin{abstract}
Healthy soils are essential for progressive agronomic activities. Organic fertilization positively affects agro-ecosystems by stimulating plant growth, enhancing crop productivity and fruit quality and improving soil fertility. Soil health and food security are the key elements of Organic Agriculture 3.0. Landfilling and/or open-dumping of animal wastes produced from slaughtering cause environmental pollution by releasing toxic substances, leachate and greenhouse gases. Direct application of animal carcasses to agricultural fields can adversely affect soil microbiota. Effective waste management technologies such as thermal drying, composting, vermicomposting and anaerobic digestion transform animal wastes, making them suitable for soil application by supplying soil high in organic carbon and total nitrogen. Recent agronomic practices applied recycled animal wastes as organic fertilizer in crop production. However, plants may not survive at a high fertilization rate due to the presence of labile carbon fraction in animal wastes. Therefore, dose calculation and determination of fertilizer application frequency are crucial for agronomists. Long-term animal waste-derived organic supplementation promotes copiotrophic microbial abundance due to enhanced substrate affinity, provides micronutrients to soils and protects crops from soil-borne pathogens owing to formation of plant-beneficial microbial consortia. Animal waste-derived organically fertilized soils possess higher urease and acid phosphatase activities. Furthermore, waste to fertilizer conversion is a low-energy requiring process that promotes circular bio-economy. Thus, considering the promotion of soil fertility, microbial abundance, disease protection and economic considerations application of animal-waste-derived organic fertilizer should be the mainstay for sustainable agriculture.
\end{abstract}

Keywords: animal waste recycling; organic fertilization; agronomic efficiency; soil health; bioeconomy; environmental sustainability

\section{Introduction}

Due to increase in the world's population and changes in their dietary habits, the global demand for food is expected to be doubled within the next few decades [1]. Particularly in India and China, the adoption of a more westernized diet can contribute about $50-70 \%$ of the total growing need as both countries together represent $37 \%$ of the world population [2]. According to Food and Agriculture Organization (FAO) of the United Nations, the world population may reach 9 billion by 2050 [3], which will create huge pressure on our growers to further accelerate agricultural production. This may be achieved either by improving the farming systems or by increasing agricultural land use [4]. To feed the constantly growing population, Sjauw-Koen-Fa [5] estimated 9\% expansion of arable land, $14 \%$ increase in cropping intensity and 77\% more yields, while Pretty and Bharucha [6] suggested sustainable intensification of agro-ecosystems rather than the enhancement of cultivable land. The Green Revolution in the late 1960s aimed to alleviate extreme poverty, malnutrition and hunger of millions. This movement converted farming to an industrial 
system, which incorporated the application of modern machinery, the use of synthetic agrochemicals and genetically modified organisms to the agro-ecosystems [1]. Unfortunately, soil salinization caused by mineral weathering and human interventions and shortage of water has made extensive areas of the total cultivable lands unproductive [7].

Chemical fertilizers sustain short-term productivity of agro-ecosystems, while their indiscriminate use reduces soil fertility, adversely affects enzymatic activity and jeopardizes copiotrophic community [8]. Copiotrophs (i.e., fast growing, $r$-strategist), are a group of microorganisms that thrive in an environment rich in organic matter, particularly carbon. They are nutritionally opposite to oligotrophs (i.e., slow growing, $k$-strategist) that live in much lower C concentrations [9]. Surviving in a nutritionally deprived/rich environment must involve expression of different sets of genes among the copiotrophs and oligotrophs. Koch [10] stated the possible reasons for oligotrophs to succumb during challenges of too high nutrition are: (a) Sudden availability of too many transportable non-metabolic substances, (b) cell death due to osmotic swelling, (c) inappropriate SOS response that means blockage of DNA synthesis and (d) generation of inactive or variable but not cultivable cells. Conventional farming practices and associated synthetic fertilizations not only pollute ground water sources but also put an unbearable burden on our farmers [11]. The majority of these inorganic substances are persistent [12], not readily degraded by natural microorganisms, which can reduce soil viability and negatively affect the quality of produce [13]. Organic agriculture is thus going to be an effective alternative worldwide. Such practices encourage quality food production excluding the use of pesticides and synthetic fertilizers, and targets equilibrium in soil dynamics. The addition of animal-derived amendments to soils promotes plant growth, crop yield and fruit quality due to balanced supply of C, $\mathrm{N}$ and $\mathrm{P}$ as well as supplying micronutrients such as zinc $(\mathrm{Zn})$, manganese $(\mathrm{Mn})$, boron (B), copper $(\mathrm{Cu})$ and iron (Fe) for crop improvement $[14,15]$. Organic farming makes the soil friable and fertile: It enhances cohesion of aggregates, accumulates massive organic matter (SOM) in soil and influences microbial communities and their co-occurrences [16]. Moreover, this can improve $\mathrm{N}$ use efficiency of crops significantly and reduce $\mathrm{NH}_{3}$ loss through volatilization [17]. Increased SOM supports vigorous uptake of nutrients, provides food for indigenous microorganisms and contributes greater $C$ sequestration in organic agro-ecosystems, as well as having a strong effect on soil aggregation [18,19]. Aggregation size, classes and stability also affect microbial communities of soil and their composition and diversity. For example, alpha- Proteobacteria was dominant in macro-aggregates with high SOM. Organic matter is divided into stable and labile fractions. Stable C fractions are highly resistant to microbial decomposition, while labile $\mathrm{C}$ proportions have a rapid turnover rate and are directly related to the plant nutrient supply [20]. Labile C fractions are $\mathrm{O}$-substituted alkyl, carbonyl and methoxyl $\mathrm{C}$ generally abundant in animal waste that are readily available to copiotrophs as energy source [21]. Recently, Bhunia et al. [15] found copiotrophs to be abundant in soils fertilized with recycled slaughterhouse waste, although it could vary with the type of organic substances amended [16]. Simultaneously, organically treated soils attained higher urease, dehydrogenase and acid phosphatase activities, which have a key role in nutrient recycling and decomposition of soil organic matter [22]. Chae et al. [23] considered $\beta$-glucosidase as a biological indicator of soil ecosystem health. In addition, organic fertilizers protect crops from Pythium, Fusarium, Verticillium, Phytopthora and Rhizoctonia like soil-borne pathogens [24], while excessive chemical fertilization posed a greater risk of pest outbreak [13]. Currently, the worldwide crop production is reduced by $36 \%$ due to emerging diseases of plants and regular pest attacks [25]. The application of organic manures provides a source of food substrates of varying quality that invoked competitions among microbial communities changing the structure and function of resident soil microbiome [26]. Few studies suggested that the production of volatile and non-volatile toxic compounds released during the decomposition of supplied organic amendment can also be the attributor of plant disease suppression [27,28]. Sturz and Christie [29] documented parasitism, competition, antibiosis, and systematic induced resistance (SIR) as possible mechanisms for allelopathic exclusion of soil-borne 
phytopathogens. Organic cultivations may gain fast acceptance globally if adverse effects of inorganic substances are highlighted with fervor.

Over the last decade, livestock production in India has also expanded. Following the slaughtering of animals, meat sectors generate organic wastes in vast quantity, which comprises $45 \%$ of the animal body weight [30]. Due to lack of government policies and proper awareness, these are either incinerated or landfilled in developing countries like India. Landfilling and/or open disposal of livestock mortalities can pose a serious threat to environment as they are the latent reservoir of Avian influenza, Salmonella, Bacillus, Brucella, Clostridium, Campylobacter and bovine spongiform encephalopathy (BSE) [31]. In addition, dumping sites release various toxic compounds, leachate and $\mathrm{CH}_{4}$ and $\mathrm{CO}_{2}$ like major greenhouse gases (GHGs) together with annoyances from bad odors to their surroundings [32]. The unscientific management of such wastes carries calculable risks to human health. For example, zoonoses caused by the infectious livestock pathogens may increase the morbidity of farm workers [33]. Indeed, animal wastes are a rich source of organic nutrients and will propagate environmental pollution if they are not utilized responsibly. Agronomic practices with untreated animal waste can introduce organic pollutants in the agro-environment and increase the number of antibiotic-resistant bacteria in soil [1]. The propagation of antibiotic resistant genes in bacteria is driven by horizontal gene transfer (HGT), and rhizosphere soil has been considered as a major hotspot for HGT [34]. Interestingly, the accumulation of heavy metals in agricultural field due to repetitive overuse of animal-derived amendments and/or raw organic waste may enhance antibiotic resistance in indigenous bacterial population [35]. The evolutionary theory of co-selection, which drives cross- (where same gene provides resistance to both antibiotic and heavy metals) and co-resistance (when resistance is offered by different genes of the same genetic loci) is found most relevant with the occurrence and propagation of antibiotic resistant genes in agricultural soil [1]. Due to emergence of antibiotic-resistant genes, an estimated 10 million human deaths will occur per year by 2050 [36]. Moreover, even plants die due to overuse of raw organic amendments in agriculture $[15,21]$. To minimize such adverse effects and to ensure biosecurity, waste recycling is necessary before reusing them in agriculture, which may also support the concept of circular bio-economy. Generally, animal wastes are treated through composting, vermicomposting, anaerobic digestion and drying methods. Sometimes, rendered meals are also used in organic farming and aquaculture [37]. Special emphasis has been given to these conversion technologies and their effects on pathogen and heavy metal removal from waste as these are the major challenges in waste to fertilizer conversion.

The emerging problems in developing countries like India appear clear: (a) Production of safe, healthy and affordable food for the constantly growing population, (b) recycling and reuse of organic waste in agriculture as fertilizer, (c) reduction in GHG emissions and environmental pollution, (d) protecting soil health and landscape diversity from synthetic applications and (e) development of a bio-based economy to achieve overall sustainability. To meet the future climatic and socio-economic challenges, agriculture needs to be organic and more productive. Adoption of Organic Agriculture 3.0 that aims to shift organic cultivation from its current domain to mainstream, may solve the problems linked with food safety and environmental health and provide an opportunity for the organic sector development [38]. This version is an advancement over the previous Organic Agriculture 2.0 and 1.0, which included socio-economic empowerment of rural areas, agroecological intensification and development in food production incorporating novel ethics and habits [39].

Our recent work, Bhunia et al. [15], demonstrated recycling of rural slaughterhouse waste through tray-drying and showed its agronomic efficiency during successive cultivation of bell pepper and amaranth, where $\mathrm{N}$ fertilization at a rate of $80 \mathrm{~kg} \mathrm{ha}^{-1}$ produced higher yield and better fruit characteristics. Earlier, Roy et al. [40,41] applied sun-dried mixture of bovine blood and rumen digesta as major $\mathrm{N}$ source for the cultivation of solanaceous vegetables in India. On the other hand, high-temperature pyrolysis converted bone-based 
animal waste to an alternative of rock phosphate for fertilizer production [42]. During pot cultivation of maize, Frazão et al. [43] used granular poultry litter as an effective $P$ substitute. Furthermore, Nunes et al. [44] grew soybean and corn with composted abattoir waste, while Arancon et al. [45] assessed positive effects of animal manure vermicompost. Feasibility of these organic fertilizers varied considerably with the feedstock type and adopted treatment technology [46]. Indeed, crop nutrient-use efficiency is highly dependent on the carbon-to-nitrogen $(\mathrm{C} / \mathrm{N})$ ratio of the substances applied during cultivations as lower $\mathrm{C} / \mathrm{N}$ value indicated a high fertilizer quality and net mineralization of $\mathrm{N}$ in soil [47].

Therefore, this review article aims to discuss: (a) Animal waste recycling and their reuse in agriculture, (b) agronomic efficiency of the animal-derived fertilizers and (c) their potential effects on biology and fertility of soil agro-ecosystems as well as (d) to develop a bio-based economy through waste-to-fertilizer conversion.

\section{Recycling Animal Waste for Fertilizer Production}

\subsection{Composted Amendment}

Under the framework of circular bio-economy, waste recycling is currently gaining much interest instead of burial and burning of livestock mortalities. Following the European Union (EU) Directive 2002/1774/EC, such traditional practices are strictly prohibited within the EU [48]. As animal wastes contain high fat and protein, they can be used as viable feedstock in various value-added applications [49]. Indeed, composting is still preferable over the decades for recycling of animal waste in agriculture, which is relatively inexpensive and also environmentally acceptable.

Biological degradation of organic waste is carried out either in presence of oxygen or in anaerobic mode. Composting is an aerobic route of organic waste valorization that typically occurs in four consecutive phases, namely mesophilic, thermophilic, cooling and maturation. During the initial stage of composting, mesophilic activities increase compost temperature up to $68^{\circ} \mathrm{C}$ that can facilitate faster proliferation of thermophiles [50]. Therefore, the second phase entails efficient eradication of pathogens to ensure biosafety. However, some opportunistic pathogens such as BSE and Salmonella may re-colonize the compost when temperature begins to decrease in subsequent cooling stage [51]. At maturation, the composted material becomes a friable, inodorous and humus-like nutrient rich product that can replace commercial inorganic fertilizers, improving soil properties through supplying essential crop nutrients. The main factors that could affect the quality and content of compost are waste $\mathrm{C} / \mathrm{N}$ ratio, mode of composting, decomposition conditions and addition of nutrients during the process [46].

Three types of composting systems are currently employed, including windrows, static bins and in-vessel composting. Franke-Whittle and Insam [30] recommended windrow composting of animal carcasses as it reduced the pathogenic load better than the in-vessel type. According to Senesi et al. [52], the presence of humic acid fractions in organic compost makes it ecofriendly and agronomically acceptable. Animal waste composting can be considered beneficial in terms of the microbial stabilization, pathogen inactivation, moisture reduction and good fertilizer quality of the end product [53]. Ragályi and Kádár [54] applied slaughterhouse compost as fertilizer in agriculture. Poultry hatchery waste comprised of infertile eggs, dead chickens, decaying tissues and blood contaminated wastewater which contained $1 \% \mathrm{~N}, 2.5 \% \mathrm{P}$ and $0.2 \% \mathrm{~K}$ when it was composted with poultry litter as reviewed by Glatz et al. [55], while Nunes et al. [44] found $18.2 \%$ organic C, $1.8 \%$ $\mathrm{N}$ and $2 \% \mathrm{P}$ in cattle manure compost. Furthermore, fertilization with immature compost can increase soil salinity, facilitate $\mathrm{N}$ immobilization due to higher $\mathrm{C} / \mathrm{N}$ ratio and suppress plant growth enhancing osmotic stress [56], whereas maturate compost with a $\mathrm{C} / \mathrm{N}$ ratio lower than 20 may act as valuable soil conditioner [50]. Moreover, Bhunia et al. [31] suggested additional thermal treatments to make the compost pathogen-free. 


\subsection{Vermicompost Manure}

Like composting, this technology is also involved in organic waste stabilization under aerobic environment. Vermicomposting has emerged as a sustainable option with two major benefits of transmuting plant available nutrients into much more soluble forms along with simultaneous reduction in total as well as bioavailable heavy metals content [57]. Simply, vermicompost is a mixture of worm cast, humus, live earthworms and their cocoons. It is a finely divided peat-like material that is rich in NPK, essential micronutrients and beneficial microbial communities including $\mathrm{N}_{2}$-fixing, P-solubilizing bacteria and actinobacteria [58]. Today, vermicompost has become an imperative component of organic farming systems as the product has better nutrient profile and higher microbial status than traditionally available compost manures [59]. In general, vermicompost fertilization improves quality of agricultural produce and can be physical, chemical and biological attributors of the soil health.

Vermicomposting, an efficient biotechnological approach of composting, employs certain earthworm species to turn the organic waste into nutrient-rich manure, during which organic fractions of solid waste are modified by associated microbial communities secreting hydrolytic enzymes, while the earthworms used accelerate the process through substrate aeration, mixing, grinding, fragmentation and enzymatic digestion [57,60]. Out of the thousands of species of earthworms, Eisenia fetida was found to be the most appropriate epigeic one for vermicomposting of animal waste and biogas plant slurry [61]. After 10-15 days of primary decomposition, earthworms were incorporated at 8-10 worms kg-1 of waste in specified composting bed, where the earthworm activity undergoes two distinct phases: An initial active phase followed by the maturation or aging stage $[62,63]$.

At maturation, vermicompost turns dark-brown, non-sticky and odorless with a final moisture range between 25 and 30\% and may then be harvested from the top of the heap separating applied earthworms. Atiyeh et al. [64] cultivated marigolds using pig manure vermicompost. Yadav et al. [61] assessed around 2.8\% N, 1\% P and 0.9\% K from earthwormprocessed cow waste, while Garczyńska et al. [65] showed that vermicompost derived from Cameroon sheep dung had an organic C content of $34 \%$, total $\mathrm{N}$ of $1.7 \%, \mathrm{P}$ of $1 \%$ and $\mathrm{K}$ of $1.3 \%$. Previously, Borges et al. [66] reported that the mixture of cow and swine manure (in 50:50 ratio) provided greater mineral composition in final vermi-produce. The use of immature vermicompost may introduce crop toxicity. On the other hand, diseasecausing plant pathogens such as Pythium, Rhizoctonia and Verticillium are suppressed when mature vermicompost is applied at a moderate rate [67]. Moreover, these can incorporate huge amount of organic matter into agricultural soils, thereby improving soil aeration, aggregation stability, water-holding capacity and nutrient availability as well as stimulate enzyme and soil microbial activity. Kumazawa et al. [68] briefly documented beneficial roles of organic matter in sustainable agricultural production.

As vermicomposting technology does not involve any thermophilic phase, complete eradication of livestock pathogens in the final product is not guaranteed, although the process surprisingly reduced enteric virus, fecal coliforms and Salmonella strains in various biosolids [69]. Tognetti et al. [59] inoculated earthworms after the thermophilic stage of composting to overcome the drawback. According to Swati and Hait [57], used earthworms can reduce the mobility of metal ions converting them into lesser available forms who also found such mobile metal ions were accumulated in earthworm tissues.

\subsection{Anaerobically Produced Digestate}

Anaerobic digestion is a series of biological process (namely hydrolysis, acidogenesis, acetogenesis and methanogenesis) that facilitates organic matter breakdown in the absence of oxygen to produce biogas that may be an alternative source of energy to replace fossil fuels. A nutrient-rich product is also derived at the end of this process known as digestate. Anaerobic digestion can be either mesophilic (at $35^{\circ} \mathrm{C}$ for $15-30$ days) or thermophilic (at $55{ }^{\circ} \mathrm{C}$ for $12-14$ days) and effectively removes pathogens and pollutants from the 
digestate produced, which may then be separated into solid and liquid fractions to fertilize agricultural soils [70-72].

A wide array of organic wastes including agrarian, municipal and sewage sludge can be the feedstock of anaerobic digestion [1]. During this process, the plant-available

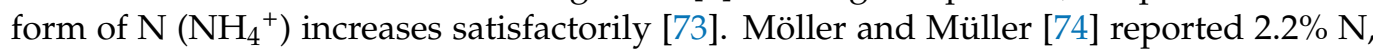
$0.4 \% \mathrm{P}$ and $0.9 \% \mathrm{~K}$ in pig slurry digestate derived from German biogas plants, while some solid digestates contained $51-61 \%$ mineral $\mathrm{N}$ that suggested their best use would be as fertilizer [72]. Moreover, digestate application could reduce the risks of P runoff as labile-P fractions are significantly decreased in anaerobic digestion [75]. Few studies have addressed the fertilizer value of anaerobically produced digestate. For example, Nkoa et al. [76] found poultry-derived liquid digestate to be more suitable for high $\mathrm{N}$ demanding crops with a short-growing period. Loria et al. [77] used swine manure digestate as $\mathrm{N}$ source in corn production, while Collins et al. [78] fertilized potato plants with P-rich animal manure digestate. Furthermore, digestates from animal slurries can be an efficient source of nutrients for vegetable production even under the soilless condition as reviewed by Möller and Müller [74].

In recent years, the effects of anaerobic digestion process on pathogen inactivation and pollutants removal have also been considered for sustainable management of soil fertility. The majority of the slaughterhouse pathogens such as Salmonella, Giardia and Cryptosporidium were destroyed just after $30 \mathrm{~min}$ of thermophilic digestion [79], whereas Viau and Peccia [80] failed to eradicate such pathogens adopting the mesophilic process. Masse et al. [81] acknowledged composting as a more effective way for reducing antibiotic residues from organic waste instead of anaerobic digestion. Thus, composting was recently performed extensively along with anaerobic digestion to improve the digestate quality [31], while aerobic post-treatment of anaerobically digested poultry waste was suggested by Salminen et al. [82] to reduce its phytotoxic effects.

\subsection{Pyrolysed Biochar}

Biochar is a carbon-rich charcoal-like organic substance obtained from pyrolysis of biomass waste, which is usually applied as soil conditioner/amender in order to improve agro-ecosystem health and crop productivity and can also reduce the adverse effects of phytopathogens [83]. This technology involves thermochemical degradation of waste materials under an oxygen-deprived environment at elevated temperature, and can be divided into three subclasses as conventional, fast and flash pyrolysis depending on their operating conditions. According to Demirbas and Arin [84], a low process temperature and heating rate would maximize the char production, while Uzoma et al. [85] pyrolyzed cow manure at $500{ }^{\circ} \mathrm{C}$ temperature to obtain a biochar with $0.1 \% \mathrm{~N}, 0.8 \% \mathrm{P}$ and $3.3 \%$ organic $\mathrm{C}$ content. Biochar quality parameters namely $\mathrm{pH}$ level, surface area, pore structures, functional groups and elemental compositions differ widely with pyrolysis substrate and temperature [86]. Zwetsloot et al. [42] showed how pyrolysis temperature affected availability and chemistry of $P$ in abattoir bone char. In a recent study, Zhang et al. [87] established that higher-temperature pyrolysis reduced environmental risks and heavy metal toxicity in biochar derived from cow manure.

Biochar application may resolve a diversity of issues including site-specific (e.g., reduction in plant available contaminants) to global-scale problems (e.g., atmospheric $C$ sequestration, GHG mitigation) [88]. Due to the presence of recalcitrant $C$ fraction in biochar, such amendments become resistant to microbial attacks and stay in soil for thousands of years, even though high internal surface area and porous structure of biochar facilitate an ideal habitat for colonization, growth and reproduction of bacteria, actinobacteria and mycorrhizal fungi $[89,90]$. Thus, biochar addition could promote a potential sink for organic C [91]. It also augmented water and nutrient retention, plant growth, enzymatic activity and cation/anion exchange ability of soil as well as prevented surface water eutrophication and environmental deterioration associated with the extensive use of chemical fertilizers [83]. Indeed, biochar can restore phosphorus sustainability in organic 
agro-ecosystems. Wang et al. [92] amended soils with poultry-derived biochar rather than raw litter application to reduce the risks of phosphorus leaching, while Glaser and Lehr [93] reviewed that biochars produced from agrarian residues significantly increased $P$ availability in agricultural soils. It was also reported that animal manure biochars contained more organic nutrients compared to the biochars prepared from plant materials [94]. Moreover, biochar usages in combination with other organic amendments keep the soil healthy by positively affecting microbial community structure and soil dehydrogenase activity. Such fertilization favored higher crop yield [95], although the agronomic efficiency of animal-derived biochars was not yet fully explored.

\subsection{Dried Animal Waste}

After proper heat treatment, organic wastes are generally transformed into either animal/ fish feed or nutritious organic fertilizer [49]. Drying is a simple technique of heat and mass transfer that allows low-cost recycling of animal waste in agriculture as stated by Bhunia et al. [96]. EU Directive 1990/667/EC suggested that drying of biomass waste at $133{ }^{\circ} \mathrm{C}$ for 20 min may completely eradicate infectious pathogens from the process end product [97]. Kádár [98] utilized dried slaughterhouse compost for sugar beet cultivation in Hungary, while Roy et al. [40] cook-dried the mixture of abattoir-derived bovine blood and rumen digesta (BBRDM) in different ratios $(1: 1,2: 1$ and 3:1) to assess its fertilizer potential, reduce the extensive use of chemical fertilizers and to provide a clean environment around rural slaughterhouses. During field cultivations of tomato, Roy et al. [41] applied the same fertilizer (3:1), which contained $4.9 \% \mathrm{~N}, 0.6 \% \mathrm{P}$ and $0.9 \% \mathrm{~K}$ along with a $4.8 \mathrm{C} / \mathrm{N}$ ratio. In our recent study, Bhunia et al. [15] showed agronomic potential of tray-dried slaughterhouse waste, where the mixture (in 3:1 ratio) was dried at $100-120^{\circ} \mathrm{C}$ for $6-8 \mathrm{~h}$ using a designed tray dryer system. Drying type and process temperature had significant influence on the quality of end product as we observed during our research. We also developed a new drying equipment for on-site production of the fertilizer in India. A patent has been filed on this equipment by Bhowmik et al. [99] with application number 202031033116. On the other hand, Roy et al. [100] showed the effective eradication of Mycobacterium, Salmonella, Clostridium, Bacillus, Brucella and E. coli O157:H7 adopting the drying technology. Our previous study [15] also confirmed the absence of the above-mentioned abattoir pathogens in BBRDM-fertilized soils through 16S rRNA metagenomic study. Table 1 summarizes waste conversion methods and fertilizer quality of the final produce.

Table 1. Nutritional status of organic fertilizers derived from different animal sources.

\begin{tabular}{|c|c|c|c|c|c|}
\hline \multirow[t]{2}{*}{ Amendment Type } & \multirow[t]{2}{*}{ Used Feedstock } & \multicolumn{3}{|c|}{ Fertilizer Value (\%) } & \multirow[t]{2}{*}{ References } \\
\hline & & $\mathbf{N}$ & $\mathbf{P}$ & $\mathbf{K}$ & \\
\hline \multirow{2}{*}{ Composted fertilizer } & Poultry hatchery waste & 1 & 2.5 & 0.2 & Glatz et al. [55] \\
\hline & Cow & 1.8 & 2 & 0.1 & Nunes et al. [44] \\
\hline \multirow{2}{*}{ Vermicompost manure } & Cow & 2.8 & 1 & 0.9 & Yadav et al. [61] \\
\hline & Sheep & 1.7 & 1 & 1.3 & Garczyńska et al. [65] \\
\hline \multirow{2}{*}{ Anaerobic digestate } & Poultry & 16.4 & 2.4 & 1.9 & Salminen et al. [82] \\
\hline & Pig & 2.2 & 0.4 & 0.9 & Möller and Müller [74] \\
\hline Pyrolysed biochar & Cow & 0.1 & 0.8 & - & Uzoma et al. [85] \\
\hline Dried amendment & Buffalo & 4.9 & 0.6 & 0.9 & Roy et al. [40,41] \\
\hline
\end{tabular}

\section{Dose Calculation and Yield Potential Assessment}

Today, the use of fertilizers in agriculture is obvious in order to meet the growing need for food. In general, fertilization maximizes crop productivity and yields better quality of produce by supplying essential plant nutrients directly or indirectly to the soils. Bhunia et al. [15] observed early-stage mortality of bell pepper plants when cultivated with 
excessive supply of $\mathrm{N}$ through BBRDM fertilization $\left(180 \mathrm{~kg} \mathrm{~N} \mathrm{ha}^{-1}\right)$, while $\mathrm{N}$ application at low $\left(80 \mathrm{~kg} \mathrm{~N} \mathrm{ha}^{-1}\right)$ and moderate $\left(120 \mathrm{~kg} \mathrm{~N} \mathrm{ha}^{-1}\right)$ rates showed profound crop yield and better fruit quality. Previously, Roy et al. [40] experienced the same problem when cook-dried abattoir waste was added to soils in higher quantity $\left(180 \mathrm{~kg} \mathrm{ha}^{-1}\right)$ at the time of planting, where fertilizer $\mathrm{N}$ content was not considered for dose calculation. Indeed, the presence of labile $\mathrm{C}$ fractions in animal waste and higher accumulation of $\mathrm{NH}_{4}{ }^{+}-\mathrm{N}$ in soil due to their overuse may arrest vegetative growth of plants and induce phytotoxicity $[15,21]$. Previously, Bonanomi et al. [101] claimed a significant reduction in phytotoxicity, which was associated with the progressive decrease in O-alkyl-C fractions. Lazcano et al. [102] found higher tomato plants death due to rigorous use of compost manure and suggested that the application dosages need to be well controlled. Furthermore, Lim et al. [67] reported the application of vermicomposted manure at a higher rate could reduce crop yield due to availability of soluble salts in vermicomposts. In the case of anaerobically produced digestate, some ambiguity also exists over its agronomic effectiveness. Gutser et al. [73] stated that crops, mainly the vegetable varieties, were unable to uptake readily available form of $\mathrm{N}$ in a huge amount, which led to greater leaching risk. Therefore, special emphasis should be given on fertilizer dose calculation and its application frequency determination.

According to Jackson and Smith [103], while studying the effects of fertilizer application rate and time on grain yields, noted that animal manures are a potential source of $\mathrm{N}$ for cereal crops. Sradnick and Feller [104] established that commercially available organic fertilizers obtained from plant and animal sources generally contained a higher amount of $\mathrm{N}$ than P. Moreover, Hua et al. [105] showed that animal manure application increased crop productivity enhancing $\mathrm{N}$ use efficiency in the soils of a 40-year soybean-maize rotation. Based on the above discussion, we also realize that agronomic efficiency of animal-derived fertilizers is highly dependent on its $\mathrm{N}$ availability. In contrast, various studies considered animal waste as a source of $\mathrm{P}$ in sustainable agriculture $[42,75,106]$. Judicious use of animal manures maximizes economic returns increasing crop yield per unit of fertilizer applied [107]. Agronomic efficiency (AE) is a metric that includes yield potential of an applied fertilizer and relates directly to economic return [108]. In the majority of the reports, agronomic efficiency was calculated straightforward: Yield data/rate of fertilizer application as stated by Vanlauwe et al. [109], although during our study, we have calculated agronomic efficiency adopting the formula of López-Bellido and López-Bellido [110]. Mathematically, this can be expressed as:

$$
\mathrm{AE}=\frac{\text { (Yield in fertilized soil }- \text { Yield in unfertilized soil })}{\text { Quantity of fertilizer supplied }}
$$

During the field cultivation of wheat, Koutroubas et al. [111] found no significant differences in dry matter yield between the control and soils fertilized with $16 \mathrm{tha}^{-1}$ farmyard manure (FYM), while the application of composted animal manure (composting of farm wastes along with poultry manure in 3:1 ratio) at a rate of $10 \mathrm{t} \mathrm{ha}^{-1}$ attained greater maize productivity than $4 \mathrm{tha}^{-1}$ as reported by Adediran et al. [112]. Roy et al. [41] applied $225 \mathrm{~kg} \mathrm{ha}^{-1}$ dried mixture of bovine blood and rumen digesta (produced in 3:1 ratio as mentioned earlier) to obtain $33 \mathrm{tha}^{-1}$ tomato yields. Authors claimed that, during the cultivation, they had provided $68.31 \mathrm{~kg} \mathrm{~N} \mathrm{ha}^{-1}$ of soil, whereas Adekiya and Agbede [113] recorded $7.6 \mathrm{t} \mathrm{ha}^{-1}$ yield of tomato supplying $30 \mathrm{tha}^{-1}$ poultry manure (PM). In another study where the effects of poultry manure, wood ash and rice bran were evaluated, MoyinJesu [114] found that relative to other treatments, the application of $6 \mathrm{t} \mathrm{PM} \mathrm{ha}^{-1}$ provided better cabbage head yield. Similarly, Evanylo et al. [115] assessed the effectiveness of commercial fertilizer, poultry litter and compost-based manures in an organic vegetable cropping system who reported the highest maize growth around $16.2 \mathrm{tha}^{-1}$ in soils fertilized with $2 \mathrm{t} \mathrm{ha}^{-1}$ dried poultry litter (DPL) as shown in Table 2. In contrast, PM addition did not affect maize yield satisfactorily as reported by Busari et al. [116]. On the other hand, Ragályi and Kádár [54] preferred fertilization with composted cattle waste (CCW) at a 25-50 tha ${ }^{-1}$ application rate instead of chemical use for higher triticale production in 
Hungary. After three years, Nunes et al. [44] cultivated soybean and maize plants with the same fertilizer at different dosages $\left(0,4,8,12\right.$ and $\left.16 \mathrm{t} \mathrm{ha}^{-1}\right)$ and found a quadratic relationship between the crop yield and fertilization rate. Furthermore, Das et al. [117] confirmed that composted cattle waste was agronomically more efficient than applied swine manure compost in rice paddy. On the other hand, fertilization with vermicompost manure also demonstrated the same trend of grain yield. For example, Arancon et al. [45] recorded $16 \mathrm{tha}^{-1}$ marketable yield of bell pepper upon the application of $10 \mathrm{tha}^{-1}$ vermicomposted cow manure (VCM). In addition, Llaven et al. [118] showed that peppers treated with sheep manure vermicompost produced better-quality fruits, although vermicompost derived from cow manure (CMV) was not satisfactory according to Joshi et al. [119]. However, the market acceptance of vermicomposts is greater than the composted products probably due to the better visual aspects, larger nutrient concentrations and higher microbial population size and activity [59]. According to Rayne and Aula [120], the degree to which manure affects agro-ecosystem potential is not only dependent on its fertilizer value, but also on the rate and timing of application, soil type and climatic conditions. Conversely, the use of anaerobically produced digestate and biochar in organic farming is not very popular. Alburquerque et al. [121] achieved $44 \mathrm{tha}^{-1}$ crop yield by adding $6 \mathrm{t} \mathrm{ha}^{-1}$ digested pig slurry (DPS) to the field soils. Bougnom et al. [122] applied solid anaerobic digestate, rather than the manure, to obtain higher yield of hay plants. Furthermore, Uzoma et al. [85] assessed the yield potential of cow manure biochar (CMB) during maize cultivation in Japan. Moreover, pyrolyzed biochar could reduce the risk of nutrient leaching [92]. According to Karim and Ramasamy [123], lower fertilization rates always tended to higher fertilizer use efficiency, thus agronomic efficiency was also higher. Vanlauwe et al. [109] established a negative exponential relationship between the $\mathrm{AE}$ and amount of $\mathrm{N}$ fertilizer supplied, while Chuan et al. [124] showed a positive quadratic correlation among yield response and AE for NPK dosages as illustrated in Figure 1. Simply, higher agronomic efficiency indicates more proficient use of nutrients mainly $\mathrm{N}$ by the crops, although developing countries generally practiced price-based selection of fertilizer. Table 2 represents the yield potential of various animal-derived amendments at different dosages where the fertilization rates and crop yield are calculated on a dry matter basis.

Lund and Doss [125] found a strong residual impact of dairy cattle manure on plant health and soil fertility. McAndrews et al. [126] evaluated residual effects of composted swine manure measuring growth and yield parameters of field soybean. Authors reported 0.2 to $0.5 \mathrm{tha}^{-1}$ productivity, which was higher than the control as well as urea-treated residual plots. Ragályi and Kádár [54] provided evidence of greater residual fertility in soils treated with CCW even after 3-4 years of cultivation. Recently, Bhunia et al. [15] proved that dried animal waste was residually more efficient than the soils treated with chemical fertilizers and market available vermicomposts. 
Table 2. Yield potential of various animal-derived amendments at different dosages (expressed as dry matter basis).

\begin{tabular}{|c|c|c|c|c|c|}
\hline Study Country & Fertilizer Type & $\begin{array}{l}\text { Application Rate } \\
\left(t \mathbf{h a}^{-1}\right)\end{array}$ & Cultivated Crops & $\begin{array}{l}\text { Yield Response } \\
\left.\text { (t ha }{ }^{-1}\right)\end{array}$ & References \\
\hline \multirow{3}{*}{ Greece } & \multirow{3}{*}{ FYM } & 0 & \multirow{3}{*}{ Wheat } & 3.2 & \multirow{3}{*}{ Koutroubas et al. [111] } \\
\hline & & 16 & & 3.4 & \\
\hline & & 32 & & 4.5 & \\
\hline \multirow{5}{*}{ Nigeria } & \multirow{5}{*}{$\begin{array}{l}\text { FYM+PM }(3: 1) \\
\text { compost }\end{array}$} & 0 & \multirow{5}{*}{ Maize } & 1.6 & \multirow{5}{*}{ Adediran et al. [112] } \\
\hline & & 2.5 & & 2.1 & \\
\hline & & 5 & & 2.2 & \\
\hline & & 7.5 & & 2.4 & \\
\hline & & 10 & & 4.0 & \\
\hline \multirow{3}{*}{ Nigeria } & \multirow{3}{*}{ PM } & 0 & \multirow{3}{*}{ Maize } & 1.9 & \multirow{3}{*}{ Busari et al. [116] } \\
\hline & & 5 & & 3.7 & \\
\hline & & 10 & & 2.9 & \\
\hline \multirow{5}{*}{ Hungary } & \multirow{5}{*}{$\mathrm{CCW}$} & 0 & & 5.2 & \multirow{5}{*}{ Ragályi and Kádár [54] } \\
\hline & & 25 & & 5.4 & \\
\hline & & 50 & Triticale & 4.7 & \\
\hline & & 100 & & 6.7 & \\
\hline & & 200 & & 6.4 & \\
\hline \multirow{4}{*}{ India } & \multirow{4}{*}{ CMV } & 0 & \multirow{4}{*}{ Wheat } & 2 & \multirow{4}{*}{ Joshi et al. [119] } \\
\hline & & 5 & & 3 & \\
\hline & & 10 & & 3.1 & \\
\hline & & 20 & & 3.1 & \\
\hline \multirow{2}{*}{ United States } & \multirow{2}{*}{ DPL } & 0 & \multirow{2}{*}{ Maize } & 2.4 & \multirow{2}{*}{ Evanylo et al. [115] } \\
\hline & & 2 & & 16.2 & \\
\hline \multirow{4}{*}{ Japan } & \multirow{4}{*}{$\mathrm{CMB}$} & 0 & \multirow{4}{*}{ Maize } & 1.2 & \multirow{4}{*}{ Uzoma et al. [85] } \\
\hline & & 10 & & 1.3 & \\
\hline & & 15 & & 3.1 & \\
\hline & & 20 & & 2.4 & \\
\hline
\end{tabular}

FYM: Farmyard manure, PM: poultry manure, CCW: composted cattle waste, CMV: cattle manure vermicompost, DPL: dried poultry litter, CMB: cow manure biochar.

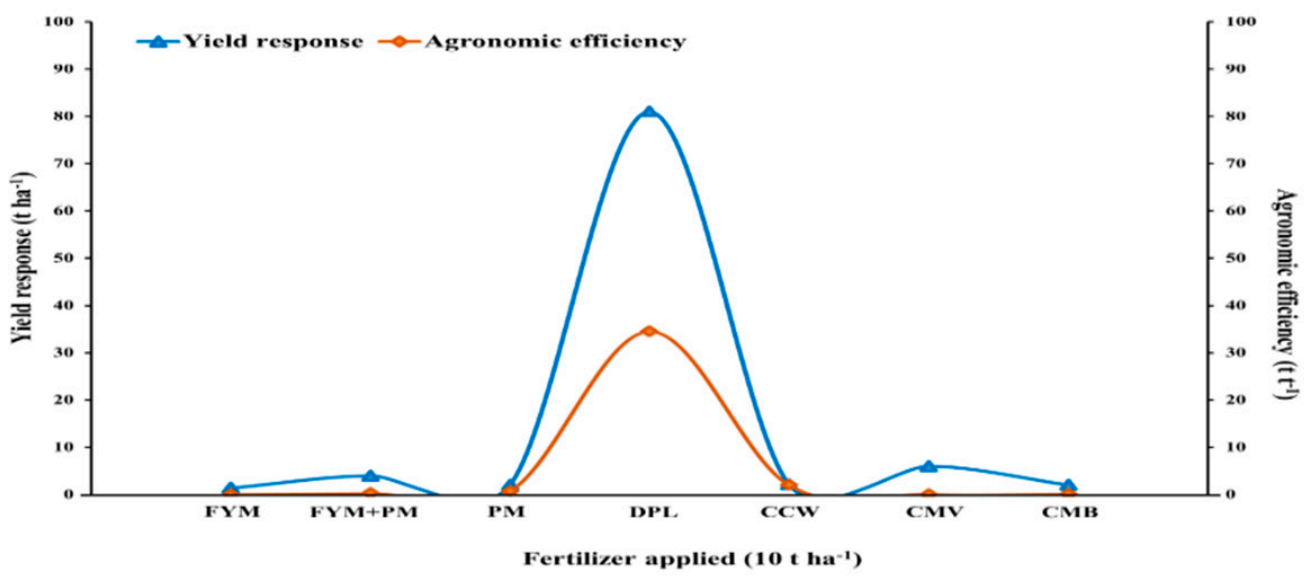

Figure 1. Positive quadratic correlation between the yield response and AE, where application rate was kept constant at $10 \mathrm{t} \mathrm{ha}^{-1}$ as dry weight basis for all the used fertilizers. This curve behaves quadratically as the highest exponent of the variable in the curve-equation was a square and the relationship found positive as increasing one variable increases the other one. Details provided in Table 2. FYM: Farmyard manure, PM: Poultry manure, DPL: Dried poultry litter, CCW: Composted cattle waste, CMV: Cattle manure vermicompost, CMB: Cow manure biochar. 


\section{Effects on Agro-Ecosystem Health}

\subsection{Aggregate Formation}

Organic fertilization through the use of recycled animal waste provides sufficient strength for building up soil fertility especially in regions where soils are nutritionally poor [127]. Healthy soils are by default stable, resilient to stress factors and largely diverse with numerous taxa that form a complex food web through high levels of nutrient recycling [128]. The formation of stable aggregates may sustain crop productivity improving soil structure that provides pathways for the transportation of water, elements and gases as well as facilitates an ideal environment for microbial growth. Interestingly, aggregation stability is mainly dependent on the SOM content and dynamics [129]. Few studies reported that long-term inorganic fertilization promoted cohesion of aggregates [130-132], while no changes or even decrease was observed by Bandyopadhyay et al. [133], Xin et al. [134] and Zhou et al. [135] in comparison to unfertilized plots. In contrast, the addition of organic amendments enhanced SOM bound soil particles together into aggregates. Zhang et al. [136,137] showed a positive correlation between the aggregation stability and associated binding agents. Furthermore, it was reported that organic application decreased the proportion of microaggregates $(<250 \mu \mathrm{m})$ with the mean geometric diameter and accumulated more SOM in macro-aggregates $(>250 \mu \mathrm{m})$, as shown in Table 3. According to Lin et al. [16], microaggregates with recalcitrant SOM had less favorable habitat conditions due to greater cooperation and competition among the microbial groups, and found that the classes Gaiellales and Pezizales were abundant in micro-aggregates. Indeed, micro-aggregates with lower SOM chose Actinobacteria adopting the $k$-selection strategy, while Proteobacteria was dominant in macro-aggregates with high labile SOM [138]. In addition, Ma et al. [139] demonstrated that a deficiency in labile SOM enhanced both competition and cooperation among soil microbes. However, the degree of aggregation was highly influenced by the type of organic fertilizers amended and the presence of indigenous microbial communities in arable soil. Guo et al. [140] incorporated straw manure to improve structural stability of the soil, while cattle manure appeared to increase macro-aggregate proportion [141]. Furthermore, Lin et al. [16] showed more effective soil aggregation, around 30.6\% larger aggregate formation in soils treated with pig manure instead of plant residues or inorganic NPK, whereas Babalola et al. [142] reported a 15.7\% increase in aggregation stability after the addition of green manure compost. In addition, poultry litter usages reduced the formation of micro-aggregates by $34 \%$ compared to chemical fertilizer treatment and stimulated glomalin production [143]. On the other hand, Li-Xian et al. [144] mentioned that animal manure application with high salt content degraded soil structure to some extent.

\subsection{SOM Turnover}

Organic matter is a key component of arable soil, which is essential for long-term productivity of an agro-ecosystem as it contains N, P, C and other nutrients indispensable for growing plants and an energy reservoir for soil heterotrophic fauna [19] and has a priming effect on global carbon cycle as well [145]. Increasing SOM level interestingly decreases bulk density, which augments water retention, air exchange capacity and root proliferation [146]. It is well documented that the extensive use of chemical fertilizers deteriorated soil health mainly reducing the SOM content and associated microbial communities. According to Ali et al. [147], the SOM content in arable soils can be lower due to intensive cultivation throughout the year. In order to increase the SOM level, organic farming is preferred as suggested by Liang et al. [22], Maillard and Angers [148] and Wang et al. [149] because organic agriculture could replenish SOM more than that lost. The SOM cycling, formation and decomposition, is mainly mediated by the structure, composition and activity of indigenous microbial communities [150,151]. Later, Tian et al. [152] stated that fertilization deliberately influenced SOM content and quality affecting the composition of microbial communities. However, Kong et al. [153] reported that the turnover rate could also be influenced by the factors like irrigation, crop-rotation, soil environment and climate change. 
A large number of field experiments have revealed that the long-term manure application alone or in combination enhanced SOM content and its fractions, while Gregorich et al. [154] did not find any significant alteration in the turnover rate of SOM under continuous chemical supplementation. Additionally, Whalen et al. [155] reported that the soil organic carbon (SOC) and total nitrogen (TN) concentration were increased up to 2.02 and $0.24 \mathrm{t} \mathrm{ha}^{-1} \mathrm{yr}^{-1}$, respectively, when composted cattle manure was added to farmland soils. Similarly, Brown and Cotton [156] found a three-fold higher SOC level in compost-amended soil, while Majumder et al. [157] observed NPK + FYM fertilized plots had similar labile C pool in comparison to the control. Bouajila and Sanaa [158] showed that matured compost application responded better to SOM fractions than the fresh or immature one due to the presence of higher stable C. Dass et al. [159], Jayakumar et al. [160] and Zhao et al. [161] experienced the same effects with animal manure vermicompost. Previously, Compton and Boone [162] showed how soil $\mathrm{N}$ dynamics was affected by the quality and quantity of SOC. According to Lal [163], fertilization affects SOC pools mainly increasing the humification rate. During the organic cultivation of tomato by land application of dried buffalo waste, Roy et al. [41] evidenced a temporary increase in plant-available soil $\mathrm{N}$ that may be due to lack of $\mathrm{N}$ immobilization, while in applying animal-derived biochar in organically fertilized soils, Plaza et al. [164] documented a drastic reduction in soil C loss through organo-mineral complex formation. Furthermore, Lin et al. [16] obtained highest TN and SOM value in NPK + pig manure soil. Authors amended plant residue with virgin NPK that did not affect SOM level significantly in comparison to control treatment. However, readily available SOC and high TN content allowed faster proliferation of copiotrophs as reported by Zhan et al. [165], which are involved in decomposition of organic matter to supply essential plant nutrients. We can consider them as potential indicators of healthy soil.

\subsection{Microbial Abundance and Community Composition}

Soil microbes are an integral part of agro-ecosystem health, can be classified as bacteria, actinobacteria, cyanobacteria, fungus, mycorrhizae, protozoa, algae, and each of them has a specific function in maintaining soil quality. According to Moeskops et al. [166], these serve residue decomposition, nutrient cycling, $\mathrm{N}$ fixation, $\mathrm{C}$ sequestration and stable aggregate formation as well as having a major role in soil-borne disease suppression. Moreover, the ability of organisms to degrade SOM depends on their enzyme secretion potential [129]. An active microflora is therefore crucial for sustainable crop production. Xu et al. [167] considered rhizosphere microbes as early warning indicators of soil health as they respond quickly to environmental changes. Indeed, the abundance, structure and activities of such indigenous microbial communities could be greatly influenced by the composition of plant species, agricultural practices and various abiotic factors as stated previously by Yu et al. [168]. Their responses towards diverse fertilization regimes have been well studied by so many authors over the past several years. Geisseler and Scow [169] found a $15.1 \%$ increase in microbial biomass production and diversity upon the application of mineral fertilizers compared to non-fertilized plots, but later on Wang et al. [170] observed a dramatic reduction in bacterial richness under the same fertilization regime. In contrast, Roy et al. [40] obtained higher numbers (in terms of $\mathrm{cfu} \mathrm{mL} \mathrm{m}^{-1}$ ) of total bacteria, $\mathrm{N}$ fixing Azotobacter, P-solubilizing bacteria, cyanobacteria and fungi in soils fertilized dried abattoir waste, whereas rice husk biochar only increased the abundance of genera Thiobacillus, Pseudomonas and Flavobacterium that contributed to P availability in soil [171]. In addition, Gopal et al. [172] confirmed that the populations of Azotobacter, Azospirillum, Nitrobacter, ammonifying bacteria and P-solubilizers were superior in Eudrilus sp. composted cow manure. The repetitive overuse of ammoniacal fertilizers significantly reduced the $\mathrm{pH}$ level in soil, which is closely associated with decreased microbial diversity and changes in indigenous community composition, while the addition of animal-derived amendments to soils prevented the acidification problem and related effects on soil microbiota as stated by Sun et al. [173]. However, it is very difficult to understand the complex responses of 
microbial communities towards organic and conventional farming as both the fertilization regimes have different bacterial and fungal populations (Table 3 ).

During their studies, Chaudhry et al. [174], Wang et al. [170] and Li et al. [175] demonstrated copiotrophic abundance in soils, which was managed organically, while Li et al. [176] observed a slow recovery of oligotrophs when SOC and TN levels were decreased in arable field with the progression of time. Oligotrophs and copiotrophs are physiological traits and can be distinguished by their growth kinetics and substrate affinity for metabolism. Chen et al. [177] obtained a higher Michaelis-Menten constant for copiotrophs that usually stayed in environments with high nutrient levels and preferentially consumed the labile C pools, while in contrast, oligotrophs exploit a soil that is nutritionally poor with low energy flow but, have higher biomass yield for each unit of substrate consumed [9]. Thus, oligotrophs are less reactive to abrupt resource availability and relatively slow-growing. Studies suggested that the main driving factor behind such shifts in community compositions may be the type of organic $\mathrm{C}$ incorporated and not the application of $\mathrm{P}$ and N [178-180]. The inability of copiotrophs to grow under nutrient-deprived condition includes possessing a relatively lower affinity for the substrate combined with a lack of adequate regulatory mechanisms for starvation as reported by Koch [10]. By applying the copiotroph-oligotroph concept to soil microorganisms, we can make specific predictions about the ecological attributions of various taxa and understanding of structure and function of resident bacterial communities in better way. Furthermore, Ding et al. [181] specified the roles of $\mathrm{pH}$ in shaping bacterial community structure who found Proteobacteria, Acidobacteria and Actinobacteria to be pre-dominant in the combined application of NPK + organic manure. Jones et al. [182] recorded the highest Acidobacterial abundance in chemically fertilized soils with a lower $\mathrm{pH}$ level. However, Shanks et al. [183] documented Bacteroidetes as the most abundant phyla in soils amended with composted cattle manure, whereas $\mathrm{Li}$ et al. [176] did not find any significant change in relative abundance when they compared the compost with control treatment. Moreover, the genus Thermogemmatispora (phylum Chloroflexi) was reported as key stone taxa in pig manured soils by Lin et al. [16] who noticed a decrease in its relative abundance under the NPK + pig manure treatment. On the other hand, fertilization with vermicompost manure at $3.75 \mathrm{t} \mathrm{ha}^{-1}$ rate diminished the richness of oligotrophic Actinobacteria, Acidobacteria and Gemmatimonadetes [184]. In a recent study, Bhunia et al. [15] obtained copiotrophic Proteobacteria, Planctomycetes, Bacteroidetes, Chloroflexi and Firmicutes as dominant in soils from bell pepper rhizosphere following the application of recycled slaughterhouse waste, while their richness diminished when treated with $\mathrm{N} / \mathrm{P} / \mathrm{K}=10: 26: 26$ + urea. Likewise, Wu et al. [185] observed that Nitrosospira abundance in organically fertilized soils that belonged to the $\beta$-subclass of Proteobacteria improved fertilizer $\mathrm{N}$ use efficiency during the cultivation of grapes. Compared to bacteria, fungus poses more oligotrophic features as they prefer nutrient-rich environment to grow, therefore, the species of fungal phylum Basidiomycota including Irpex, Pycnoporus, Trametes, Schizophyllum and Fomes predominantly show oligotrophy in organic soils [186]. However, Wang et al. [170] demonstrated more ecologically similar groups in arable soils after the addition of organic fertilizers that indicated less interaction between the microbes.

\subsection{Enzymatic Activity}

Soil enzymes are also crucial for maintaining agro-ecosystem productivity. According to Das and Varma [187], ß-glucosidase, dehydrogenase, phosphatase, urease and invertase are the major enzymes that are generally found abundant in agricultural soils. The majority of these enzymes directly originate from viable microbial cells [188]. Their activities together with microbial biomass C (MBC) express biological status of the soil at a given time, and therefore enzyme levels can be used to determine the degree of alteration in soil structure. Moreover, Shi [189] established a positive correlation between the organic matter turnover and enzymatic activity in agricultural soils, whereas Lupwayi et al. [190] showed how MBC and activities of some of the enzymes (B-glucosidase, NAGase, acid phosphomonoesterase and arylsulphatase) that mediate major biogeochemical cycles were 
affected by manure applications at different dosages. Additionally, soil enzymes are found highly sensitive to $\mathrm{pH}$ changes, while different fertilizers responded differently to the soil $\mathrm{pH}$ [191], although it is well documented that these enzymatic activities were enhanced when soils were fertilized with organic amendments. For instance, the activity of alkaline phosphomonoesterase in clay loamy soils was increased up to $300 \mathrm{mg} p$-NP $\mathrm{kg}^{-1} \mathrm{~h}^{-1}$ with the addition of swine manure biochar at the rate of $0.5 \%$, which was around $150 \mathrm{mg}$ p-nitrophenyl phosphate $(p-\mathrm{NP}) \mathrm{kg}^{-1} \mathrm{~h}^{-1}$ in control treatment [192]. Lupwayi et al. [190] obtained 1956 pmol methylumbelliferone (MUF) $\mathrm{g}^{-1} \mathrm{~h}^{-1}$ B-glucosidase activity in soils amended with composted cattle manure, whereas the NPK fertilized plots had 1534 pmol MUF $\mathrm{g}^{-1} \mathrm{~h}^{-1}$ activity of ß-glucosidase. Antonious et al. [193] monitored soil enzyme activity before and after animal manure application and found an increased urease and invertase activities after incorporation of vermicomposted horse manure to native soils. Furthermore, Panuccio et al. [194] showed a higher dehydrogenase activity (255 $\mu \mathrm{g}$ trifenil tetrazolium formazan or TTF $\mathrm{g}^{-1} \mathrm{~h}^{-1}$ ) in loamy-sand soil, which was treated with $50 \%$ solid digestate produced from anaerobic digestion of animal manure and maize silage mixture, relative to control treatment $\left(70 \mu \mathrm{g} \mathrm{TTF} \mathrm{g}^{-1} \mathrm{~h}^{-1}\right)$. These positive results reflect higher metabolic profile of soil under organic farming systems.

Table 3. Alteration in agro-ecosystem health under different fertilization regimes.

\begin{tabular}{|c|c|c|c|}
\hline \multirow[t]{2}{*}{$\begin{array}{l}\text { Soil Health } \\
\text { Parameters }\end{array}$} & \multicolumn{2}{|c|}{ Type of Fertilizer Applied } & \multirow[t]{2}{*}{ References } \\
\hline & Chemical & Organic & \\
\hline Aggregate formation & $\begin{array}{l}\text { Increases the proportion of } \\
\text { micro-aggregates in soil }(<250 \mu \mathrm{m})\end{array}$ & $\begin{array}{l}\text { Accumulates more SOM in } \\
\text { macro-aggregates }(>250 \mu \mathrm{m})\end{array}$ & Lin et al. [16] \\
\hline SOM turnover & $\begin{array}{l}\text { No significant alteration in SOM } \\
\text { turnover rate }\end{array}$ & $\begin{array}{l}\text { More labile SOC pools in } \\
\text { organically fertilized soils }\end{array}$ & $\begin{array}{c}\text { Gregorich et al. [154]/Brown } \\
\text { and Cotton [156] }\end{array}$ \\
\hline Microbial abundance & $\begin{array}{c}\text { Oligotrophic } \\
\text { (Actinobacteria, Acidobacteria and } \\
\text { Gemmatimonadetes) }\end{array}$ & $\begin{array}{c}\text { Copiotrophic } \\
\text { (Proteobacteria, Bacteroidetes, } \\
\text { Firmicutes and Planctomycetes) }\end{array}$ & Bhunia et al. [15] \\
\hline Enzymatic activity & $\begin{array}{l}\text { Relatively less but greater than the } \\
\text { control treatment }\end{array}$ & Higher & Lupwayi et al. [190] \\
\hline Disease suppression & Poses a greater risk of pest outbreak & $\begin{array}{l}\text { Protects crops from Pythium, } \\
\text { Fusarium, Verticillium, } \\
\text { Phytopthora and Rhizoctonia } \\
\text { like soil-borne pathogens }\end{array}$ & $\begin{array}{l}\text { Kim et al. [13]/Bailey and } \\
\text { Lazarovits [24] }\end{array}$ \\
\hline
\end{tabular}

\subsection{Disease Suppression}

Research shows that the disease suppression ability of a crop is mainly confined to the biological properties of soil [195]. As highlighted in the literature, organic fertilizers can also be beneficial in terms of their disease suppression potential, while extensive and imbalanced supply of virgin nutrients pose a greater risk of pest outbreak decreasing the natural resistance in crops [13]. In recent years, the emergence of novel soil-borne plant pathogens and their resistant behaviors towards various phytochemicals have become a challenge to agricultural biologists. However, crops grown in organically cultivated soils exhibited lower attacks of pests and diseases as stated by Bailey and Lazarovits [24] (Table 3). Among the considered amendment types, composted fertilizers and vermicompost manures are generally applied to manage plant diseases and pests attacks without affecting the environment and human health, although their effectiveness against phytopathogens is attributed to microbial populations and community interactions present within these recycled products [196]. Yatoo et al. [197] claimed that vermicompost had better ability to resist plant diseases in comparison to commercial compost manures. Previously, Manandhar and Yami [198] found vermicompost to possess highest efficiency of disease control when they compared the effect of composted and vermicomposted fertilizers on foot rot 
disease of rice caused by Fusarium moniliforme. Arancon et al. [199] reported similar results applying vermicompost manure against spider mites attack to tomato seedlings, while wilt disease of tomato plants caused by the infection of Fusarium oxysporum was effectively suppressed when soil fertilized with dairy solid-based vermicompost [200]. Likewise, Szczech and Smolinska [201] assured that vermicompost application derived from animal manures prevented the abundance of pathogenic Phytophthora nicotianae. Pane et al. [202] recorded better inhibition in mycelial growth of Pythium, Sclerotinia and Rhizoctonia upon the addition of animal manure-based composts. In contrast, Bonanomi et al. [203] reported Rhizoctonia solani to thrive on animal-derived amendments rich in sugar-containing labile carbon fractions. In a continuation, Bonanomi et al. [21] demonstrated that organic amendments with high labile $C$ fractions would be conducive to plant damping-off disease in short-term but, became suppressive after 100-300 days of application. Recently, Tao et al. [204] showed that the addition of bio-organic fertilizer shielded plants from pathogen infection increasing synergistic formation of biofilm at the root-microbiome interface, which may act as a plant-beneficial consortium against the soil-borne phytopathogens. An overall depiction of animal waste recycling and their reuse in farming systems to intensify agricultural productivity is reflected in Figure 2.

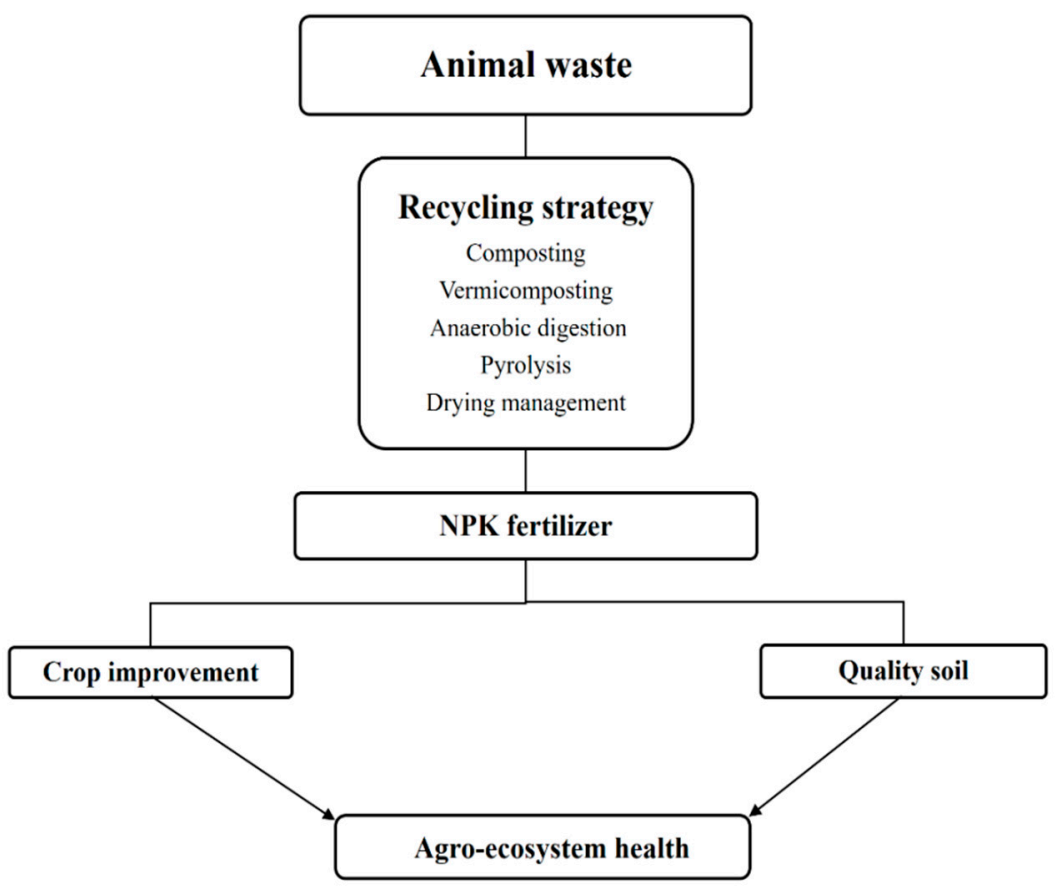

Figure 2. An approach to achieve agricultural sustainability through waste to fertilizer conversion.

\section{Circulation of Nutrients Together with Economy}

In this section, we will discuss how a bio-based economy is developed through wasteto-fertilizer conversion. In recent years, the per capita consumption of meat is increasing day after day leading to huge production of animal wastes daily. As we mentioned earlier, most of the time, these wastes are not properly disposed of, which adversely affects the environment and society as well as leading to economic losses. Composting, vermicomposting, anaerobic digestion, pyrolysis and drying are the major treatment alternatives that make such wastes suitable to supply NPK, without which food production would not be possible. This was discussed briefly in Section 2. As animal wastes have greater fertilizer value, as shown in Table 1, these may reduce the use of inorganic NPK sources in agriculture. Waste-to-fertilizer production not only improves the agro-ecology but also can be the backbone of our economy. It is necessary to shift our economic mindset from linear to circular to provide a permanent solution along with societal benefits under the framework of sustainable bio-economy practice. According to the European Com- 
mission [205], bio-economy includes the conversion of renewable bio-based wastes into diversified value-added products, which is, by default, circular as described by Carrez and Van Leeuwen [206], Sheridan [207] and Stegmann et al. [208]. This study highlighted a transition from the utilization of virgin nutrients to nutrient cycling, where nutrients are circulated together with economy.

This transition also includes efficient use of nutrients, generates demands for organic fertilizers and measures safe and profitable production and consumption of recycled nutrients as previously recommended by Valve et al. [209]. Figure 3 represents a pictorial overview of circular nutrient economy, which reflects economic, agricultural and environmental sustainability in each step. It starts with the waste production from different livestock farms and meat processing units, and then such wastes are recycled into organic fertilizers like compost, vermicompost, anaerobic digestate and biochar. When these amendments are applied in agriculture, SOM turnover as well as the $\mathrm{C} / \mathrm{N}$ ratio of soil increases. Such fertilizers also supplies micro-nutrients that are indispensable for plant growth, thus a noticeable improvement in crop productivity was observed by Zhang et al. [14] and Bhunia et al. [15] during their studies. In fact, animal-derived organic amendments can positively affect the structure, nutrient turnover and many other properties of the soil as we briefed in Section 4. Human and livestock consumption of plant produce closed the nutrient loop, which will start again with the slaughtering of livestock animals. This novel approach can recirculate the economy transforming nutrient flows from linear to circular. Adopting this approach, local farmers, livestock owners and meat producing sectors would be benefited creating a ground for profitable business.

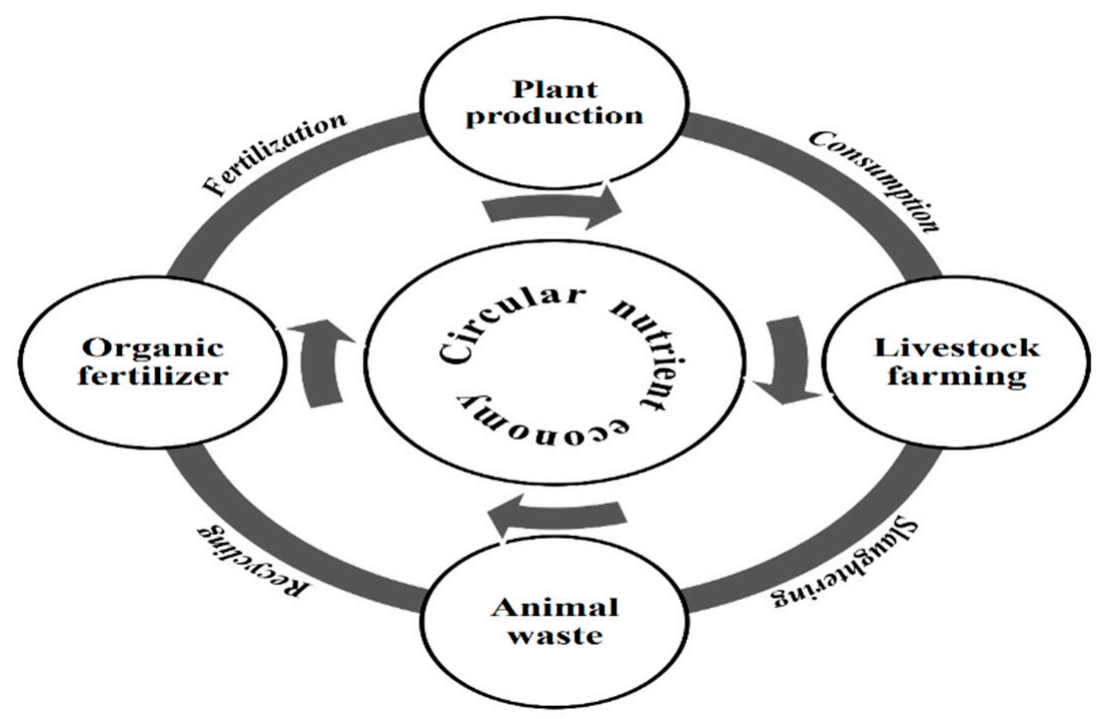

Figure 3. Circular nutrient economy and its elements.

\section{Conclusions}

Nutrient recycling through waste to fertilizer conversion safely disposes of livestock waste without polluting the environment. Among the existing conversion alternatives, composting, vermicomposting and thermal drying are relatively cost-effective and environmentally sound methods that can satisfactorily incorporate animal nutrients into the soil agro-ecosystem, which may be lost due to improper disposal of animal waste. No single technology can allow the complete destruction of abattoir pathogens, mainly the re-survival problem of BSE. Thus, the use of techniques in combinations is preferable, although adoption of dry heating technology may be advantageous in rural meat sectors. This review has categorized animal-derived amendments according to their source of origin and treatment technology adopted for recycling and highlighted how dose calculation and determination of fertilizer application frequency are crucial for maximizing crop production and soil fertility. A positive quadratic correlation between the yield 
response and agronomic efficiency was established by meta-analysis and the effects of diverse animal-derived fertilizers on soil aggregate formation, SOM turnover, microbial abundance, enzymatic activity and soil-borne disease suppression were also studied. In this study, a special emphasis has been given to the inactivation of waste pathogens that generally contaminate the rhizosphere soil if not treated properly before the land use. We furthermore conclude that, rather than the use of chemical fertilizers, the application of properly recycled animal-derived amendments at the appropriate dose will be more beneficial in terms of cost saving, agro-environmental quality and better crop productivity that should be the mainstay for sustainable agriculture. The main feature of this research is the circular nutrient economy, which exemplified how nutrients circulate together with the economy and affects sustainable development of the society. In view of animal waste valorization, future research on the circular nutrient economy should be encouraged to introduce organic fertilizers into mainstream cultivation.

Author Contributions: Conceptualization, J.M.; writing-original draft preparation, S.B. and A.B.; writing-review and editing, J.M.; supervision, J.M. and R.M. All authors have read and agreed to the published version of the manuscript.

Funding: This research work received no external funding for publication.

Data Availability Statement: No new data were created or analyzed in this study. Data sharing is not applicable to this article.

Acknowledgments: Authors thank Anupam Debsarkar, Associate Professor of Department of Civil Engineering, Jadavpur University for his helpful suggestions. We are also grateful to the anonymous Reviewers whose comments vastly improved the manuscript.

Conflicts of Interest: Authors declare that they have no conflict of interest.

\section{References}

1. Urra, J.; Alkorta, I.; Garbisu, C. Potential benefits and risks for soil health derived from the use of organic amendments in agriculture. Agronomy 2019, 9, 542. [CrossRef]

2. Gandhi, V.P.; Zhou, Z. Food demand and the food security challenge with rapid economic growth in the emerging economies of India and China. Food Res. Int. 2014, 63, 108-124. [CrossRef]

3. FAO. Food and Agriculture Organization of the United Nations. 2050: A Third More Mouths to Feed. 2009. Available online: http:/ / www.fao.org/news/story/en/item/35571/icode/ (accessed on 25 January 2021).

4. Bommarco, R.; Kleijn, D.; Potts, S.G. Ecological intensification: Harnessing ecosystem services for food security. Trends Ecol. Evol. 2013, 28, 230-238. [CrossRef]

5. Sjauw-Koen-Fa, A. Sustainability and Security of the Global Food Supply Chain; Rabobank Group: Haarlem, The Netherlands, 2010; pp. 8-17.

6. Pretty, J.; Bharucha, Z.P. Sustainable intensifcation in agricultural systems. Ann. Bot. 2014, 114, 1571-1596. [CrossRef]

7. Diacono, M.; Montemurro, F. Effectiveness of organic wastes as fertilizers and amendments in salt-affected soils. Agriculture 2015, 5, 221-230. [CrossRef]

8. Ansari, R.A.; Mahmood, I. Optimization of organic and bio-organic fertilizers on soil properties and growth of pigeon pea. Sci. Hortic. 2017, 226, 1-9. [CrossRef]

9. Pershina, E.; Valkonen, J.; Kurki, P.; Ivanova, E.; Chirak, E.; Korvigo, I.; Provorov, N.; Andronov, E. Comparative analysis of prokaryotic communities associated with organic and conventional farming systems. PLoS ONE 2015, 10, e0145072. [CrossRef] [PubMed]

10. Koch, A.L. Oligotrophs versus copiotrophs. Bioessays 2001, 23, 657-661. [CrossRef]

11. Tal, A. Making conventional agriculture environmentally friendly: Moving beyond the glorification of organic agriculture and the demonization of conventional agriculture. Sustainability 2018, 10, 1078. [CrossRef]

12. Geiger, F.; Bengtsson, J.; Berendse, F.; Weisser, W.W.; Emmerson, M.; Morales, M.B.; Ceryngier, P.; Liira, J.; Tscharntke, T.; Winqvist, C.; et al. Persistent negative effects of pesticides on biodiversity and biological control potential on European farmland. Basic Appl. Ecol. 2010, 11, 97-105. [CrossRef]

13. Kim, J.J.; John, K.M.; Hae-Kyung, M.; Jin, K.; Enkhtaivan, G.; Kim, D.H. Morphological and biochemical variation of Chinese cabbage (Brassica rapa spp. Pekinensis) cultivated using different agricultural practices. J. Food Compos. Anal. 2014, 36, 12-23. [CrossRef]

14. Zhang, Y.; Liu, J.; Niu, S.; Kong, M.; Zhang, J.; Lu, Y.; Yao, Y. Animal wastes as fertilizers enhance growth of young walnut trees under soil drought conditions. J. Sci. Food Agric. 2020, 100, 3445-3455. [CrossRef] 
15. Bhunia, S.; Bhowmik, A.; Mallick, R.; Debsarcar, A.; Mukherjee, J. Application of recycled slaughterhouse wastes as an organic fertilizer for successive cultivations of bell pepper and amaranth. Sci. Hortic. 2021, 280, 109927. [CrossRef]

16. Lin, Y.; Ye, G.; Kuzyakov, Y.; Liu, D.; Fan, J.; Ding, W. Long-term manure application increases soil organic matter and aggregation, and alters microbial community structure and keystone taxa. Soil Biol. Biochem. 2019, 134, 187-196. [CrossRef]

17. Zhang, M.; Yao, Y.; Tian, Y.; Ceng, K.; Zhao, M.; Zhao, M.; Yin, B. Increasing yield and N use efficiency with organic fertilizer in Chinese intensive rice cropping systems. Field Crops Res. 2018, 227, 102-109. [CrossRef]

18. Osman, K.T. Soils: Principles, Properties and Management, 1st ed.; Springer: Dordrecht, The Netherlands, 2013 ; pp. 97-110.

19. Li, S.; Li, J.; Li, G.; Li, Y.; Yuan, J.; Li, D. Effect of different organic fertilizers application on soil organic matter properties. Compost Sci. Util. 2017, 25, 31-36. [CrossRef]

20. Yan, D.; Wang, D.; Yang, L. Long-term effect of chemical fertilizer, straw, and manure on labile organic matter fractions in a paddy soil. Biol. Fertil. Soils 2007, 44, 93-101. [CrossRef]

21. Bonanomi, G.; Zotti, M.; Idbella, M.; Di Silverio, N.; Carrino, L.; Cesarano, G.; Assaeed, A.M.; Abd-ElGawad, A.M. Decomposition and organic amendments chemistry explain contrasting effects on plant growth promotion and suppression of Rhizoctonia solani damping off. PLoS ONE 2020, 15, e0230925. [CrossRef]

22. Liang, Q.; Chen, H.; Gong, Y.; Yang, H.; Fan, M.; Kuzyakov, Y. Effects of 15 years of manure and mineral fertilizers on enzyme activities in particle-size fractions in a North China Plain soil. Eur. J. Soil Biol. 2014, 60, 112-119. [CrossRef]

23. Chae, Y.; Cui, R.; Kim, S.W.; An, G.; Jeong, S.W.; An, Y.J. Exoenzyme activity in contaminated soils before and after soil washing: B-glucosidase activity as a biological indicator of soil health. Ecotoxicol. Environ. Saf. 2017, 135, 368-374. [CrossRef]

24. Bailey, K.L.; Lazarovits, G. Suppressing soil-borne diseases with residue management and organic amendments. Soil Tillage Res. 2003, 72, 169-180. [CrossRef]

25. Agrios, G.N. Plant Pathology, 5th ed.; Academic Press: San Diego, CA, USA, 2005; p. 803. [CrossRef]

26. Hoitink, H.A.J.; Boehm, M.J. Biocontrol within the context of soil microbial communities: A substrate-dependent phenomenon. Annu. Rev. Phytopathol. 1999, 37, 427-446. [CrossRef] [PubMed]

27. Chen, W.; Hoitink, H.A.J.; Tuovinen, O.H. The role of microbial activity in suppression of damping-off caused by Pythium ultimum. Phytopathology 1987, 78, 314-322. [CrossRef]

28. De Brito Alvarez, M.A.; Gagne, S.; Antoun, H. Effect of compost on rhizosphere microflora of the tomato and on the incidence of plant growth-promoting rhizobacteria. Appl. Environ. Microbiol. 1995, 61, 194-199. [CrossRef]

29. Sturz, A.V.; Christie, B.R. Beneficial microbial allelopathies in the root zone: The management of soil quality and plant disease with rhizobacteria. Soil Tillage Res. 2003, 72, 107-123. [CrossRef]

30. Franke-Whittle, I.H.; Insam, H. Treatment alternatives of slaughterhouse wastes, and their effect on the inactivation of different pathogens: A review. Crit. Rev. Microbiol. 2013, 39, 139-151. [CrossRef]

31. Bhunia, S.; Bhowmik, A.; Mukherjee, J. Waste management of rural slaughterhouses in developing countries. In Advanced Organic Management: Sustainable Practices and Approaches; Hussain, C.M., Hait, S., Eds.; Elsevier: Amsterdam, The Netherlands, 2021; accepted.

32. Domingo, J.L.; Nadal, M. Domestic waste composting facilities: A review of human health risks. Environ. Int. 2009, 35, 382-389. [CrossRef]

33. Miskiewicz, A.; Kowalczyk, P.; Oraibi, S.M.; Cybulska, K.; Misiewicz, A. Bird feathers as potential sources of pathogenic microorganisms: A new look at old diseases. Antonie Leeuwenhoek 2018, 111, 1493-1507. [CrossRef]

34. Van Elsas, J.D.; Bailey, M.J. The ecology of transfer of mobile genetic elements. FEMS Microbiol. Ecol. 2002, 42, 187-197. [CrossRef]

35. Bondarczuk, K.; Markowicz, A.; Piotrowska-Seget, Z. The urgent need for risk assessment on the antibiotic resistance spread via sewage sludge land application. Environ. Int. 2016, 87, 49-55. [CrossRef]

36. O'Neill, J. Tackling Drug-Resistant Infections Globally: Final Report and Recommendations; The Review on Antimicrobial Resistance; Wellcome Trust: London, UK, 2016.

37. Salminen, E.; Rintala, J. Anaerobic digestion of organic solid poultry slaughterhouse waste-A review. Bioresour. Technol. 2002, 83, 13-26. [CrossRef]

38. Arbenz, M.; Gould, D.; Stopes, C. ORGANIC 3.0-The vision of the global organic movement and the need for scientific support. Org. Agric. 2017, 7, 199-207. [CrossRef]

39. Rahmann, G.; Ardakani, M.R.; Bàrberi, P.; Boehm, H.; Canali, S.; Chander, M.; David, W.; Dengel, L.; Erisman, J.W.; GalvisMartinez, A.C.; et al. Organic Agriculture 3.0 is innovation with research. Org. Agric. 2017, 7, 169-197. [CrossRef]

40. Roy, M.; Karmakar, S.; Debsarcar, A.; Sen, P.K.; Mukherjee, J. Application of rural slaughterhouse waste as an organic fertilizer for pot cultivation of solanaceous vegetables in India. Int. J. Recycl. Org. Waste Agric. 2013, 2, 1-11. [CrossRef]

41. Roy, M.; Das, R.; Debsarcar, A.; Sen, P.K.; Mukherjee, J. Conversion of rural abattoir wastes to an organic fertilizer and its application the field cultivation of tomato in India. Renew. Agric. Food Syst. 2016, 31, 350-360. [CrossRef]

42. Zwetsloot, M.J.; Lehmann, J.; Solomon, D. Recycling slaughterhouse waste into fertilizer: How do pyrolysis temperature and biomass additions affect phosphorus availability and chemistry? J. Sci. Food Agric. 2015, 95, 281-288. [CrossRef]

43. Frazão, J.J.; de Melo Benites, V.; Ribeiro, J.V.S.; Pierobon, V.M.; Lavres, J. Agronomic effectiveness of a granular poultry litterderived organomineral phosphate fertilizer in tropical soils: Soil phosphorus fractionation and plant responses. Geoderma 2019, 337, 582-593. [CrossRef] 
44. Nunes, W.A.G.D.A.; Menezes, J.F.S.; Benites, V.D.M.; Lima Junior, S.A.D.; Oliveira, A.D.S. Use of organic compost produced from slaughterhouse waste as fertilizer in soybean and corn crops. Sci. Agric. 2015, 72, 343-350. [CrossRef]

45. Arancon, N.Q.; Edwards, C.A.; Bierman, P.; Metzger, J.D.; Lucht, C. Effects of vermicomposts produced from cattle manure, food waste and paper waste on the growth and yield of peppers in the field. Pedobiologia 2005, 49, 297-306. [CrossRef]

46. Chew, K.W.; Chia, S.R.; Yen, H.W.; Nomanbhay, S.; Ho, Y.C.; Show, P.L. Transformation of biomass waste into sustainable organic fertilizers. Sustainability 2019, 11, 2266. [CrossRef]

47. Gentile, R.; Vanlauwe, B.; Chivenge, P.; Six, J. Trade-offs between the short-and long-term effects of residue quality on soil C and N dynamics. Plant Soil. 2011, 338, 159-169. [CrossRef]

48. Anon. The Animal By-Products Regulations (EC) No. 1774/2002; European Commission: Brussels, Belgium, 2002.

49. Adhikari, B.B.; Chae, M.; Bressler, D.C. Utilization of slaughterhouse waste in value-added applications: Recent advances in the development of wood adhesives. Polymers 2018, 10, 176. [CrossRef]

50. Akdeniz, N. A systematic review of biochar use in animal waste composting. Waste Manag. 2019, 88, 291-300. [CrossRef] [PubMed]

51. National Agricultural Biosecurity Centre (NABC). Carcass Disposal: A Comprehensive Review; Report written for the USDA Animal and Plant Health Inspection Service; Kansas State University: Manhattan, KS, USA, 2004.

52. Senesi, N.; Plaza, C.; Brunetti, G.; Polo, A. A comparative survey of recent results on humic-like fractions in organic amendments and effects on native soil humic substances. Soil Biol. Biochem. 2007, 39, 1244-1262. [CrossRef]

53. Bernal, M.P.; Alburquerque, J.A.; Moral, R. Composting of animal manures and chemical criteria for compost maturity assessment: A review. Bioresour. Technol. 2009, 100, 5444-5453. [CrossRef]

54. Ragályi, P.; Kádár, I. Effect of organic fertilizers made from slaughterhouse wastes on yield of crops. Arch. Agron. Soil Sci. 2012, 58, 122-126. [CrossRef]

55. Glatz, P.; Miao, Z.; Rodda, B. Handling and treatment of poultry hatchery waste: A review. Sustainability 2011, 3, 216-237. [CrossRef]

56. Gajalakshmi, S.; Abbasi, S.A. Solid waste management by composting: State of the art. Crit. Rev. Environ. Sci. Technol. 2008, 38, 311-400. [CrossRef]

57. Swati, A.; Hait, S. Fate and bioavailability of heavy metals during vermicomposting of various organic wastes-A review. Process Saf. Environ. Prot. 2017, 109, 30-45. [CrossRef]

58. Ramnarain, Y.I.; Ansari, A.A.; Ori, L. Vermicomposting of different organic materials using the epigeic earthworm Eisenia foetida. Int. J. Recycl. Org. Waste Agric. 2019, 8, 23-36. [CrossRef]

59. Tognetti, C.; Laos, F.; Mazzarino, M.J.; Hernandez, M.T. Composting vs. vermicomposting: A comparison of end product quality. Compost Sci. Util. 2005, 13, 6-13. [CrossRef]

60. Maboeta, M.S.; Van Rensburg, L. Vermicomposting of industrially produced woodchips and sewage sludge utilizing Eisenia fetida. Ecotox. Environ. Saf. 2003, 56, 265-270. [CrossRef]

61. Yadav, A.; Gupta, R.; Garg, V.K. Organic manure production from cow dung and biogas plant slurry by vermicomposting under field conditions. Int. J. Recycl. Org. Waste Agric. 2013, 2, 1-7. [CrossRef]

62. Lores, M.; Gómez-Brandón, M.; Pérez-Díaz, D.; Domínguez, J. Using FAME profiles for the characterization of animal wastes and vermicomposts. Soil Biol. Biochem. 2006, 38, 2993-2996. [CrossRef]

63. Chattopadhyay, G.N. Use of vermicomposting biotechnology for recycling organic wastes in agriculture. Int. J. Recycl. Org. Waste Agric. 2012, 1, 1-6. [CrossRef]

64. Atiyeh, R.M.; Arancon, N.Q.; Edwards, C.A.; Metzger, J.D. The influence of earthworm-processed pig manure on the growth and productivity of marigolds. Bioresour. Technol. 2002, 81, 103-108. [CrossRef]

65. Garczyńska, M.; Kostecka, J.; Pączka, G.; Hajduk, E.; Mazur-Pączka, A.; Butt, K.R. Properties of vermicomposts derived from Cameroon sheep dung. Appl. Sci. 2020, 10, 5048. [CrossRef]

66. Borges, Y.V.; Alves, L.; Bianchi, I.; Espíndola, J.C.; Oliveira, J.M.D., Jr.; Radetski, C.M.; Somensi, C.A. Optimization of animal manure vermicomposting based on biomass production of earthworms and higher plants. J. Environ. Sci. Health B 2017, 52, 791-795. [CrossRef] [PubMed]

67. Lim, S.L.; Wu, T.Y.; Lim, P.N.; Shak, K.P.Y. The use of vermicompost in organic farming: Overview, effects on soil and economics. J. Sci. Food Agric. 2015, 95, 1143-1156. [CrossRef]

68. Kumazawa, K. Beneficial Effects of Organic Matter on Rice Growth and Yield in Japan. In Organic Matter and Rice; International Rice Research Institute: Manila, Philippines, 1984; pp. 431-444.

69. Pathma, J.; Sakthivel, N. Microbial diversity of vermicompost bacteria that exhibit useful agricultural traits and waste management potential. SpringerPlus 2012, 1, 1-19. [CrossRef] [PubMed]

70. Cantrell, K.B.; Ducey, T.; Ro, K.S.; Hunt, P.G. Livestock waste-to-bioenergy generation opportunities. Bioresour. Technol. 2008, 99, 7941-7953. [CrossRef]

71. Li, Y.; Park, S.Y.; Zhu, J. Solid-state anaerobic digestion for methane production from organic waste. Renew. Sustain. Energy Rev. 2011, 15, 821-826. [CrossRef]

72. Nkoa, R. Agricultural benefits and environmental risks of soil fertilization with anaerobic digestates: A review. Agron. Sustain. Dev. 2014, 34, 473-492. [CrossRef] 
73. Gutser, R.; Ebertseder, T.; Weber, A.; Schraml, M.; Schmidhalter, U. Short-term and residual availability of nitrogen after long-term application of organic fertilizers on arable land. J. Plant Nutr. Soil Sci. 2005, 168, 439-446. [CrossRef]

74. Möller, K.; Müller, T. Effects of anaerobic digestion on digestate nutrient availability and crop growth: A review. Eng. Life Sci. 2012, 12, 242-257. [CrossRef]

75. Li, B.; Dinkler, K.; Zhao, N.; Sobhi, M.; Merkle, W.; Liu, S.; Dong, R.; Oechsner, H.; Guo, J. Influence of anaerobic digestion on the labile phosphorus in pig, chicken, and dairy manure. Sci. Total Environ. 2020, 737, 140234. [CrossRef]

76. Nkoa, R.; Coulombe, J.; Desjardins, Y.; Tremblay, N. Towards optimization of growth via nutrient supply phasing: Nitrogen supply phasing increases broccoli (Brassica oleracea var. italica) growth and yield. J. Exp. Bot. 2001, 52, 821-827. [CrossRef] [PubMed]

77. Loria, E.R.; Sawyer, J.E.; Barker, D.W.; Lundvall, J.P.; Lorimor, J.C. Use of anaerobically digested swine manure as a nitrogen source in corn production. Agron. J. 2007, 99, 1119-1129. [CrossRef]

78. Collins, H.P.; Kimura, E.; Frear, C.S.; Kruger, C.E. Phosphorus uptake by potato from fertilizers recovered from anaerobic digestion. Agron. J. 2016, 108, 2036-2049. [CrossRef]

79. Côté, C.; Massé, D.I.; Quessy, S. Reduction of indicator and pathogenic microorganisms by psychrophilic anaerobic digestion in swine slurries. Bioresour. Technol. 2006, 97, 686-691. [CrossRef]

80. Viau, E.; Peccia, J. Survey of wastewater indicators and human pathogen genomes in biosolids produced by class A and class B stabilization treatments. Appl. Environ. Microbiol. 2009, 75, 164-174. [CrossRef]

81. Massé, D.I.; Saady, N.M.C.; Gilbert, Y. Potential of biological processes to eliminate antibiotics in livestock manure: An overview. Animals 2014, 4, 146-163. [CrossRef]

82. Salminen, E.; Rintala, J.; Härkönen, J.; Kuitunen, M.; Högmander, H.; Oikari, A. Anaerobically digested poultry slaughterhouse wastes as fertiliser in agriculture. Bioresour. Technol. 2001, 78, 81-88. [CrossRef]

83. Yadav, A.; Ansari, K.B.; Simha, P.; Gaikar, V.G.; Pandit, A.B. Vacuum pyrolysed biochar for soil amendment. Resour. Technol. 2016, 2, 177-185. [CrossRef]

84. Demirbas, A.; Arin, G. An overview of biomass pyrolysis. Energy Sources A 2002, 24, 471-482. [CrossRef]

85. Uzoma, K.C.; Inoue, M.; Andry, H.; Fujimaki, H.; Zahoor, A.; Nishihara, E. Effect of cow manure biochar on maize productivity under sandy soil condition. Soil Use Manag. 2011, 27, 205-212. [CrossRef]

86. Guizani, C.; Jeguirim, M.; Valin, S.; Limousy, L.; Salvador, S. Biomass chars: The effects of pyrolysis conditions on their morphology, structure, chemical properties and reactivity. Energies 2017, 10, 796. [CrossRef]

87. Zhang, P.; Zhang, X.; Li, Y.; Han, L. Influence of pyrolysis temperature on chemical speciation, leaching ability, and environmental risk of heavy metals in biochar derived from cow manure. Bioresour. Technol. 2020, 302, 122850. [CrossRef]

88. Bruckman, V.J.; Pumpanen, J. Biochar Use in Global Forests: Opportunities and Challenges. In Developments in Soil Science; Busse, M., Giardina, C.P., Morris, D.M., Page-Dumroese, D.S., Eds.; Elsevier: Amsterdam, The Netherlands, 2019 ; pp. $427-453$. [CrossRef]

89. Luo, Y.; Dungait, J.A.; Zhao, X.; Brookes, P.C.; Durenkamp, M.; Li, G.; Lin, Q. Pyrolysis temperature during biochar production alters its subsequent utilization by microorganisms in an acid arable soil. Land Degrad. Dev. 2018, 29, 2183-2188. [CrossRef]

90. Petruccelli, R.; Di Lonardo, S. Role of biochars in soil fertility management of fruit crops. In Fruit Crops; Srivastava, A.K., Hu, C., Eds.; Elsevier: Cambridge, UK, 2020; pp. 431-444. [CrossRef]

91. Verheijen, F.; Jeffery, S.; Bastos, A.C.; van der Velde, M.; Diafas, I. Biochar Application to Soils: A Critical Scientific Review of Effects on Soil Properties, Processes and Functions; European Commission Report No. EUR 24099 EN; European Communities: Ispara, Italy, 2010.

92. Wang, Y.; Lin, Y.; Chiu, P.C.; Imhoff, P.T.; Guo, M. Phosphorus release behaviors of poultry litter biochar as a soil amendment. Sci. Total Environ. 2015, 512, 454-463. [CrossRef] [PubMed]

93. Glaser, B.; Lehr, V.I. Biochar effects on phosphorus availability in agricultural soils: A meta-analysis. Sci. Rep. 2019, 9, 1-9. [CrossRef] [PubMed]

94. Shinogi, Y.; Kanri, Y. Pyrolysis of plant, animal and human waste: Physical and chemical characterization of the pyrolytic products. Bioresour. Technol. 2003, 90, 241-247. [CrossRef]

95. Brtnicky, M.; Dokulilova, T.; Holatko, J.; Pecina, V.; Kintl, A.; Latal, O.; Vyhnanek, T.; Prichystalova, J.; Datta, R. Long-term effects of biochar-based organic amendments on soil microbial parameters. Agronomy 2019, 9, 747. [CrossRef]

96. Bhunia, S.; Bhowmik, A.; Mukherjee, J. Use of rural slaughterhouse wastes (SHWs) as fertilizer in agriculture: A review. In Proceedings of the International Conference on Energy Management for Green Environment, Kolkata, India, 25-27 September 2019; pp. 1-6. [CrossRef]

97. European Commission (EC). The Veterinary Rules for the Disposal and Processing of Animal Waste; European Commission: Brussels, Belgium, 1990.

98. Kádár, I.; Hámori, V.; Morvai, B.; Petróczki, F. Soil load and pollution limit values; sewage sludge and slaughterhouse waste compost effect on sugar beet. In Cukorrépa-Termesztési/-Termeltetési Tanfolyam és Tanácskozás; Várnainé, J.A., Ed.; Cukoripari Egyesülés: Budapest, Hungary, 2002; pp. 37-40.

99. Bhowmik, A.; Bhunia, S.; Mukherjee, J. An Apparatus for Recycling Slaughterhouse Waste and Method Thereof. Indian Patent 202031033116, 2020. 
100. Roy, M.; Das, R.; Kundu, A.; Karmakar, S.; Das, S.; Sen, P.; Debsarcar, A.; Mukherjee, J. Organic cultivation of tomato in India with recycled slaughterhouse wastes: Evaluation of fertilizer and fruit safety. Agriculture 2015, 5, 826-856. [CrossRef]

101. Bonanomi, G.; Cesarano, G.; Lombardi, N.; Motti, R.; Scala, F.; Mazzoleni, S.; Incerti, G. Litter chemistry explains contrasting feeding preferences of bacteria, fungi, and higher plants. Sci. Rep. 2017, 7, 1-13. [CrossRef]

102. Lazcano, C.; Arnold, J.; Zaller, J.G.; Martín, J.D.; Salgado, A.T. Compost and vermicompost as nursery pot components: Effects on tomato plant growth and morphology. Span. J. Agric. Res. 2009, 944-951. [CrossRef]

103. Jackson, D.R.; Smith, K.A. Animal manure slurries as a source of nitrogen for cereals; effect of application time on efficiency. Soil Use Manag. 1997, 13, 75-81. [CrossRef]

104. Sradnick, A.; Feller, C. A typological concept to predict the nitrogen release from organic fertilizers in farming systems. Agronomy 2020, 10, 1448. [CrossRef]

105. Hua, W.; Luo, P.; An, N.; Cai, F.; Zhang, S.; Chen, K.; Yang, J.; Han, X. Manure application increased crop yields by promoting nitrogen use efficiency in the soils of 40-year soybean-maize rotation. Sci. Rep. 2020, 10, 1-10. [CrossRef]

106. Almeida, R.F.; Queiroz, I.D.S.; Mikhael, J.E.R.; Oliveira, R.C.; Borges, E.N. Enriched animal manure as a source of phosphorus in sustainable agriculture. Int. J. Recycl. Org. Waste Agric. 2019, 8, 203-210. [CrossRef]

107. Sharma, L.K.; Bali, S.K. A review of methods to improve nitrogen use efficiency in agriculture. Sustainability $2018,10,51$. [CrossRef]

108. Cassman, K.G.; Gines, G.C.; Dizon, M.A.; Samson, M.I.; Alcantara, J.M. Nitrogen-use efficiency in tropical lowland rice systems: Contributions from indigenous and applied nitrogen. Field Crops Res. 1996, 47, 1-12. [CrossRef]

109. Vanlauwe, B.; Kihara, J.; Chivenge, P.; Pypers, P.; Coe, R.; Six, J. Agronomic use efficiency of N fertilizer in maize-based systems in sub-Saharan Africa within the context of integrated soil fertility management. Plant Soil. 2011, 339, 35-50. [CrossRef]

110. López-Bellido, R.J.; López-Bellido, L. Efficiency of nitrogen in wheat under Mediterranean conditions: Effect of tillage, crop rotation and N fertilization. Field Crops Res. 2001, 71, 31-46. [CrossRef]

111. Koutroubas, S.D.; Antoniadis, V.; Damalas, C.A.; Fotiadis, S. Effect of organic manure on wheat grain yield, nutrient accumulation, and translocation. Agron. J. 2016, 108, 615-625. [CrossRef]

112. Adediran, J.A.; Taiwo, L.B.; Akande, M.O.; Sobulo, R.A.; Idowu, O.J. Application of organic and inorganic fertilizer for sustainable maize and cowpea yields in Nigeria. J. Plant Nutr. 2005, 27, 1163-1181. [CrossRef]

113. Adekiya, A.O.; Agbede, T.M. Effect of methods and time of poultry manure application on soil and leaf nutrient concentrations, growth and fruit yield of tomato (Lycopersicon esculentum Mill). J. Saudi Soc. Agric. Sci. 2017, 16, 383-388. [CrossRef]

114. Moyin-Jesu, E.I. Use of different organic fertilizers on soil fertility improvement, growth and head yield parameters of cabbage (Brassica oleraceae L). Int. J. Recycl. Org. Waste Agric. 2015, 4, 291-298. [CrossRef]

115. Evanylo, G.; Sherony, C.; Spargo, J.; Starner, D.; Brosius, M.; Haering, K. Soil and water environmental effects of fertilizer-, manure-, and compost-based fertility practices in an organic vegetable cropping system. Agric. Ecosyst. Environ. 2008, 127, 50-58. [CrossRef]

116. Busari, M.A.; Salako, F.K.; Adetunji, M.T. Soil chemical properties and maize yield after application of organic and inorganic amendments to an acidic soil in Southwestern Nigeria. Span. J. Agric. Res. 2008, 6, 691-699. [CrossRef]

117. Das, S.; Jeong, S.T.; Das, S.; Kim, P.J. Composted cattle manure increases microbial activity and soil fertility more than composted swine manure in a submerged rice paddy. Front. Microbiol. 2017, 8, 1702. [CrossRef] [PubMed]

118. Llaven, M.A.O.; Jimenez, J.L.G.; Coro, B.I.C.; Rincon-Rosales, R.; Molina, J.M.; Dendooven, L.; Gutierrez-Miceli, F.A. Fruit characteristics of bell pepper cultivated in sheep manure vermicompost substituted soil. J. Plant Nutr. 2008, 31, 1585-1598. [CrossRef]

119. Joshi, R.; Vig, A.P.; Singh, J. Vermicompost as soil supplement to enhance growth, yield and quality of Triticum aestivum L.: A field study. Int. J. Recycl. Org. Waste Agric. 2013, 2, 1-7. [CrossRef]

120. Rayne, N.; Aula, L. Livestock manure and the impacts on soil health: A review. Soil Syst. 2020, 4, 64. [CrossRef]

121. Alburquerque, J.A.; De la Fuente, C.; Campoy, M.; Carrasco, L.; Nájera, I.; Baixauli, C.; Caravaca, F.; Roldán, A.; Cegarra, J.; Bernal, M.P. Agricultural use of digestate for horticultural crop production and improvement of soil properties. Eur. J. Agron. 2012, 43, 119-128. [CrossRef]

122. Bougnom, B.P.; Niederkofler, C.; Knapp, B.A.; Stimpfl, E.; Insam, H. Residues from renewable energy production: Their value for fertilizing pastures. Biomass Bioenergy 2012, 39, 290-295. [CrossRef]

123. Karim, A.A.; Ramasamy, C. Expanding Frontiers of Agriculture: Contemporary Issues; Kalyani Publishers: Ludhiana, India, 2000.

124. Chuan, L.; He, P.; Pampolino, M.F.; Johnston, A.M.; Jin, J.; Xu, X.; Zhao, S.; Qiu, S.; Zhou, W. Establishing a scientific basis for fertilizer recommendations for wheat in China: Yield response and agronomic efficiency. Field Crops Res. 2013, 140, 1-8. [CrossRef]

125. Lund, Z.F.; Doss, B.D. Residual effects of dairy cattle manure on plant growth and soil properties. Agron. J. 1980, 72, 123-130. [CrossRef]

126. McAndrews, G.M.; Liebman, M.; Cambardella, C.A.; Richard, T.L. Residual effects of composted and fresh solid swine (Sus scrofa L.) manure on soybean [Glycine $\max$ (L.) Merr.] growth and yield. Agron. J. 2006, 98, 873-882. [CrossRef]

127. Chiti, T.; Gardin, L.; Perugini, L.; Quaratino, R.; Vaccari, F.P.; Miglietta, F.; Valentini, R. Soil organic carbon stock assessment for the different cropland land uses in Italy. Biol. Fertil. Soils 2012, 48, 9-17. [CrossRef]

128. Van Bniggen, A.H.; Termorskuizen, A.J. Integrated approaches to root disease management in organic farming systems. Aust. Plant Pathol. 2003, 32, 141-156. [CrossRef] 
129. Sayara, T.; Basheer-Salimia, R.; Hawamde, F.; Sánchez, A. Recycling of organic wastes through composting: Process performance and compost application in agriculture. Agronomy 2020, 10, 1838. [CrossRef]

130. Hati, K.M.; Swarup, A.; Mishra, B.; Manna, M.C.; Wanjari, R.H.; Mandal, K.G.; Misra, A.K. Impact of long-term application of fertilizer, manure and lime under intensive cropping on physical properties and organic carbon content of an Alfisol. Geoderma 2008, 148, 173-179. [CrossRef]

131. Das, B.; Chakraborty, D.; Singh, V.K.; Aggarwal, P.; Singh, R.; Dwivedi, B.S.; Mishra, R.P. Effect of integrated nutrient management practice on soil aggregate properties, its stability and aggregate-associated carbon content in an intensive rice-wheat system. Soil Tillage Res. 2014, 136, 9-18. [CrossRef]

132. Tripathi, R.; Nayak, A.K.; Bhattacharyya, P.; Shukla, A.K.; Shahid, M.; Raja, R.; Panda, B.B.; Mohanty, S.; Kumar, A.; Thilagam, V.K. Soil aggregation and distribution of carbon and nitrogen in different fractions after 41 years long-term fertilizer experiment in tropical rice-rice system. Geoderma 2014, 213, 280-286. [CrossRef]

133. Bandyopadhyay, P.K.; Saha, S.; Mani, P.K.; Mandal, B. Effect of organic inputs on aggregate associated organic carbon concentration under long-term rice-wheat cropping system. Geoderma 2010, 154, 379-386. [CrossRef]

134. Xin, X.; Zhang, J.; Zhu, A.; Zhang, C. Effects of long-term (23 years) mineral fertilizer and compost application on physical properties of fluvo-aquic soil in the North China Plain. Soil Tillage Res. 2016, 156, 166-172. [CrossRef]

135. Zhou, H.; Fang, H.; Hu, C.; Mooney, S.J.; Dong, W.; Peng, X. Inorganic fertilization effects on the structure of a calcareous silt loam soil. Agron. J. 2017, 109, 2871-2880. [CrossRef]

136. Zhang, S.; Li, Q.; Zhang, X.; Wei, K.; Chen, L.; Liang, W. Effects of conservation tillage on soil aggregation and aggregate binding agents in black soil of Northeast China. Soil Tillage Res. 2012, 124, 196-202. [CrossRef]

137. Zhang, X.; Wu, X.; Zhang, S.; Xing, Y.; Wang, R.; Liang, W. Organic amendment effects on aggregate-associated organic C, microbial biomass $C$ and glomalin in agricultural soils. Catena 2014, 123, 188-194. [CrossRef]

138. Davinic, M.; Fultz, L.M.; Acosta-Martinez, V.; Calderón, F.J.; Cox, S.B.; Dowd, S.E.; Allen, V.G.; Zak, J.C.; Moore-Kucera, J. Pyrosequencing and mid-infrared spectroscopy reveal distinct aggregate stratification of soil bacterial communities and organic matter composition. Soil Biol. Biochem. 2012, 46, 63-72. [CrossRef]

139. Ma, B.; Lv, X.; Cai, Y.; Chang, S.X.; Dyck, M.F. Liming does not counteract the influence of long-term fertilization on soil bacterial community structure and its co-occurrence pattern. Soil Biol. Biochem. 2018, 123, 45-53. [CrossRef]

140. Guo, Z.C.; Zhang, Z.B.; Zhou, H.; Rahman, M.T.; Wang, D.Z.; Guo, X.S.; Li, L.J.; Peng, X.H. Long-term animal manure application promoted biological binding agents but not soil aggregation in a Vertisol. Soil Tillage Res. 2018, 180, 232-237. [CrossRef]

141. Hurisso, T.T.; Davis, J.G.; Brummer, J.E.; Stromberger, M.E.; Mikha, M.M.; Haddix, M.L.; Booher, M.R.; Paul, E.A. Rapid changes in microbial biomass and aggregate size distribution in response to changes in organic matter management in grass pasture. Geoderma 2013, 193, 68-75. [CrossRef]

142. Babalola, O.; Adesodun, J.; Olasantan, F.; Adekunle, A. Responses of some soil biological, chemical and physical properties to short-term compost amendment. Int. J. Soil Sci. 2012, 7, 28-38. [CrossRef]

143. Bertagnoli, B.G.; Oliveira, J.F.; Barbosa, G.M.; Colozzi Filho, A. Poultry litter and liquid swine slurry applications stimulate glomalin, extraradicular mycelium production, and aggregation in soils. Soil Tillage Res. 2020, 202, 104657. [CrossRef]

144. Li-Xian, Y.; Guo-Liang, L.; Shi-Hua, T.; Gavin, S.; Zhao-Huan, H. Salinity of animal manure and potential risk of secondary soil salinization through successive manure application. Sci. Total Environ. 2007, 383, 106-114. [CrossRef]

145. Stocker, T.F.; Qin, D.; Plattner, G.-K.; Tignor, M.; Allen, J.A.; Boschung, J.; Nauels, A.; Xia, Y.; Bex, V.; Midgley, P.M. Climate Change 2013: The Physical Science Basis; Contribution of Working Group I to the Fifth Assessment Report of the Intergovernmental Panel on Climate Change; Cambridge University Press: Cambridge, UK; New York, NY, USA, 2013.

146. Smith, P.; Davies, C.A.; Ogle, S.; Zanchi, G.; Bellarby, J.; Bird, N.; Boddey, R.M.; McNamara, N.P.; Powlson, D.; Cowie, A.; et al Towards an integrated global framework to assess the impacts of land use and management change on soil carbon: Current capability and future vision. Glob. Chang. Biol. 2012, 18, 2089-2101. [CrossRef]

147. Ali, S.; Hayat, R.; Begum, F.; Bohannan, B.J.M.; Inebert, L.; Meyer, K. Variation in soil physical, chemical and microbial parameters under different land uses in Bagrot valley, Gilgit, Pakistan. J. Chem. Soc. Pak. 2017, 39, 97-107.

148. Maillard, É.; Angers, D.A. Animal manure application and soil organic carbon stocks: A meta-analysis. Glob. Chang. Biol. 2014, 20, 666-679. [CrossRef]

149. Wang, Y.; Hu, N.; Ge, T.; Kuzyakov, Y.; Wang, Z.L.; Li, Z.; Tang, Z.; Chen, Y.; Wu, C.; Lou, Y. Soil aggregation regulates distributions of carbon, microbial community and enzyme activities after 23-year manure amendment. Appl. Soil Ecol. 2017, 111, 65-72. [CrossRef]

150. Balser, T.C.; Firestone, M.K. Linking microbial community composition and soil processes in a California annual grassland and mixed-conifer forest. Biogeochemistry 2005, 73, 395-415. [CrossRef]

151. Bowles, T.M.; Acosta-Martínez, V.; Calderón, F.; Jackson, L.E. Soil enzyme activities, microbial communities, and carbon and nitrogen availability in organic agroecosystems across an intensively-managed agricultural landscape. Soil Biol. Biochem. 2014, 68, 252-262. [CrossRef]

152. Tian, J.; Lou, Y.; Gao, Y.; Fang, H.; Liu, S.; Xu, M.; Blagodatskaya, E.; Kuzyakov, Y. Response of soil organic matter fractions and composition of microbial community to long-term organic and mineral fertilization. Biol. Fertil. Soils 2017, 53, 523-532. [CrossRef]

153. Kong, A.Y.; Six, J.; Bryant, D.C.; Denison, R.F.; Van Kessel, C. The relationship between carbon input, aggregation, and soil organic carbon stabilization in sustainable cropping systems. Soil Sci. Soc. Am. J. 2005, 69, 1078-1085. [CrossRef] 
154. Gregorich, E.G.; Liang, B.C.; Ellert, B.H.; Drury, C.F. Fertilization effects on soil organic matter turnover and corn residue C storage. Soil Sci. Soc. Am. J. 1996, 60, 472-476. [CrossRef]

155. Whalen, J.K.; Benslim, H.; Jiao, Y.; Sey, B.K. Soil organic carbon and nitrogen pools as affected by compost applications to a sandy-loam soil in Québec. Can. J. Soil Sci. 2008, 88, 443-450. [CrossRef]

156. Brown, S.; Cotton, M. Changes in soil properties and carbon content following compost application: Results of on-farm sampling. Compost Sci. Util. 2011, 19, 87-96. [CrossRef]

157. Majumder, B.; Mandal, B.; Bandyopadhyay, P.K.; Chaudhury, J. Soil organic carbon pools and productivity relationships for a 34 year old rice-wheat-jute agroecosystem under different fertilizer treatments. Plant Soil. 2007, 297, 53-67. [CrossRef]

158. Bouajila, K.; Sanaa, M. Effects of organic amendments on soil physico-chemical and biological properties. J. Mater. Environ. Sci. 2011, 2, 485-490.

159. Dass, A.; Lenka, N.K.; Patnaik, U.S.; Sudhishri, S. Integrated nutrient management for production, economics, and soil improvement in winter vegetables. Int. J. Veg. Sci. 2008, 14, 104-120. [CrossRef]

160. Jayakumar, M.; Sivakami, T.; Ambika, D.; Karmegam, N. Effect of turkey litter (Meleagris gallopavo L.) vermicompost on growth and yield characteristics of paddy, Oryza sativa (ADT-37). Afr. J. Biotechnol. 2011, 10, 15295-15304. [CrossRef]

161. Zhao, H.T.; Li, T.P.; Zhang, Y.; Hu, J.; Bai, Y.C.; Shan, Y.H.; Ke, F. Effects of vermicompost amendment as a basal fertilizer on soil properties and cucumber yield and quality under continuous cropping conditions in a greenhouse. J. Soils Sediments 2017, 17, 2718-2730. [CrossRef]

162. Compton, J.E.; Boone, R.D. Soil nitrogen transformations and the role of light fraction organic matter in forest soils. Soil Biol. Biochem. 2002, 34, 933-943. [CrossRef]

163. Lal, R. Soil carbon sequestration impacts on global climate change and food security. Science 2004, 304, 1623-1627. [CrossRef] [PubMed]

164. Plaza, C.; Giannetta, B.; Fernández, J.M.; López-de-Sá, E.G.; Polo, A.; Gascó, G.; Méndez, A.; Zaccone, C. Response of different soil organic matter pools to biochar and organic fertilizers. Agric. Ecosyst. Environ. 2016, 225, 150-159. [CrossRef]

165. Zhan, Y.; Liu, W.; Bao, Y.; Zhang, J.; Petropoulos, E.; Li, Z.; Lin, X.; Feng, Y. Fertilization shapes a well-organized community of bacterial decomposers for accelerated paddy straw degradation. Sci. Rep. 2018, 8, 1-10. [CrossRef]

166. Moeskops, B.; Buchan, D.; Sleutel, S.; Herawaty, L.; Husen, E.; Saraswati, R.; Setyorini, D.; De Neve, S. Soil microbial communities and activities under intensive organic and conventional vegetable farming in West Java, Indonesia. Appl. Soil Ecol. 2010, 45, 112-120. [CrossRef]

167. Xu, L.; Yi, M.; Yi, H.; Guo, E.; Zhang, A. Manure and mineral fertilization change enzyme activity and bacterial community in millet rhizosphere soils. World J. Microbiol. Biotechnol. 2018, 34, 1-13. [CrossRef]

168. Yu, W.T.; Bi, M.L.; Xu, Y.G.; Zhou, H.; Ma, Q.; Jiang, C.M. Microbial biomass and community composition in a Luvisol soil as influenced by long-term land use and fertilization. Catena 2013, 107, 89-95. [CrossRef]

169. Geisseler, D.; Scow, K.M. Long-term effects of mineral fertilizers on soil microorganisms-A review. Soil Biol. Biochem. 2014, 75, 54-63. [CrossRef]

170. Wang, J.; Song, Y.; Ma, T.; Raza, W.; Li, J.; Howland, J.G.; Huang, Q.; Shen, Q. Impacts of inorganic and organic fertilization treatments on bacterial and fungal communities in a paddy soil. Appl. Soil Ecol. 2017, 112, 42-50. [CrossRef]

171. Liu, S.; Meng, J.; Jiang, L.; Yang, X.; Lan, Y.; Cheng, X.; Chen, W. Rice husk biochar impacts soil phosphorous availability, phosphatase activities and bacterial community characteristics in three different soil types. Appl. Soil Ecol. 2017, 116, 12-22. [CrossRef]

172. Gopal, M.; Gupta, A.; Sunil, E.; Thomas, G.V. Amplification of plant beneficial microbial communities during conversion of coconut leaf substrate to vermicompost by Eudrilus sp. Curr. Microbiol. 2009, 59, 15-20. [CrossRef]

173. Sun, R.; Zhang, X.X.; Guo, X.; Wang, D.; Chu, H. Bacterial diversity in soils subjected to long-term chemical fertilization can be more stably maintained with the addition of livestock manure than wheat straw. Soil Biol. Biochem. 2015, 88, 9-18. [CrossRef]

174. Chaudhry, V.; Rehman, A.; Mishra, A.; Chauhan, P.S.; Nautiyal, C.S. Changes in bacterial community structure of agricultural land due to long-term organic and chemical amendments. Microb. Ecol. 2012, 64, 450-460. [CrossRef] [PubMed]

175. Li, W.; Liu, M.; Wu, M.; Jiang, C.; Kuzyakov, Y.; Gavrichkova, O.; Feng, Y.; Dong, Y.; Li, Z. Bacterial community succession in paddy soil depending on rice fertilization. Appl. Soil Ecol. 2019, 144, 92-97. [CrossRef]

176. Li, F.; Chen, L.; Zhang, J.; Yin, J.; Huang, S. Bacterial community structure after long-term organic and inorganic fertilization reveals important associations between soil nutrients and specific taxa involved in nutrient transformations. Front. Microbiol. 2017, 8, 187. [CrossRef] [PubMed]

177. Chen, Y.; Chen, G.; Robinson, D.; Yang, Z.; Guo, J.; Xie, J.; Fu, S.; Zhou, L.; Yang, Y. Large amounts of easily decomposable carbon stored in subtropical forest subsoil are associated with r-strategy-dominated soil microbes. Soil Biol. Biochem. 2016, 95, 233-242. [CrossRef]

178. Eilers, K.G.; Lauber, C.L.; Knight, R.; Fierer, N. Shifts in bacterial community structure associated with inputs of low molecular weight carbon compounds to soil. Soil Biol. Biochem. 2010, 42, 896-903. [CrossRef]

179. Shi, S.; Richardson, A.E.; O'Callaghan, M.; DeAngelis, K.M.; Jones, E.E.; Stewart, A.; Firestone, M.K.; Condron, L.M. Effects of selected root exudate components on soil bacterial communities. FEMS Microbiol. Ecol. 2011, 77, 600-610. [CrossRef] [PubMed] 
180. Pascault, N.; Ranjard, L.; Kaisermann, A.; Bachar, D.; Christen, R.; Terrat, S.; Mathieu, O.; Lévêque, J.; Mougel, C.; Henault, C.; et al. Stimulation of different functional groups of bacteria by various plant residues as a driver of soil priming effect. Ecosystems 2013, 16, 810-822. [CrossRef]

181. Ding, J.; Jiang, X.; Ma, M.; Zhou, B.; Guan, D.; Zhao, B.; Zhou, J.; Cao, F.; Li, L.; Li, J. Effect of 35 years inorganic fertilizer and manure amendment on structure of bacterial and archaeal communities in black soil of northeast China. Appl. Soil Ecol. 2016, 105, 187-195. [CrossRef]

182. Jones, R.T.; Robeson, M.S.; Lauber, C.L.; Hamady, M.; Knight, R.; Fierer, N. A comprehensive survey of soil acidobacterial diversity using pyrosequencing and clone library analyses. ISME J. 2009, 3, 442-453. [CrossRef]

183. Shanks, O.C.; Kelty, C.A.; Archibeque, S.; Jenkins, M.; Newton, R.J.; McLellan, S.L.; Huse, S.M.; Sogin, M.L. Community structures of fecal bacteria in cattle from different animal feeding operations. Appl. Environ. Microbiol. 2011, 77, 2992-3001. [CrossRef] [PubMed]

184. Liu, M.; Wang, C.; Liu, X.; Lu, Y.; Wang, Y. Saline-alkali soil applied with vermicompost and humic acid fertilizer improved macroaggregate microstructure to enhance salt leaching and inhibit nitrogen losses. Appl. Soil Ecol. 2020, 156, 103705. [CrossRef]

185. Wu, L.; Jiang, Y.; Zhao, F.; He, X.; Liu, H.; Yu, K. Increased organic fertilizer application and reduced chemical fertilizer application affect the soil properties and bacterial communities of grape rhizosphere soil. Sci. Rep. 2020, 10, 1-10. [CrossRef]

186. Ho, A.; Di Lonardo, D.P.; Bodelier, P.L. Revisiting life strategy concepts in environmental microbial ecology. FEMS Microbiol. Ecol. 2017, 93, fix006. [CrossRef]

187. Das, S.K.; Varma, A. Role of Enzymes in Maintaining Soil Health. In Soil Enzymology; Shukla, G., Varma, A., Eds.; Springer: Berlin/Heidelberg, Germany, 2010; pp. 25-42. [CrossRef]

188. Nannipieri, P.; Trasar-Cepeda, C.; Dick, R.P. Soil enzyme activity: A brief history and biochemistry as a basis for appropriate interpretations and meta-analysis. Biol. Fertil. Soils 2018, 54, 11-19. [CrossRef]

189. Shi, W. Agricultural and ecological significance of soil enzymes: Soil carbon sequestration and nutrient cycling. In Soil Enzymology; Shukla, G., Varma, A., Eds.; Springer: Berlin/Heidelberg, Germany, 2010; pp. 43-60. [CrossRef]

190. Lupwayi, N.Z.; Zhang, Y.; Hao, X.; Thomas, B.W.; Eastman, A.H.; Schwinghamer, T.D. Linking soil microbial biomass and enzyme activities to long-term manure applications and their nonlinear legacy. Pedobiologia 2019, 74, 34-42. [CrossRef]

191. Effron, D.; de la Hora, A.M.; Defrieri, R.L.; Fontanive, V.; Palma, P.M. Effect of cadmium, copper, and lead on different enzyme activities in a native forest soil. Commun. Soil Sci. Plant Anal. 2004, 35, 1309-1321. [CrossRef]

192. Jin, Y.; Liang, X.; He, M.; Liu, Y.; Tian, G.; Shi, J. Manure biochar influence upon soil properties, phosphorus distribution and phosphatase activities: A microcosm incubation study. Chemosphere 2016, 142, 128-135. [CrossRef]

193. Antonious, G.F.; Turley, E.T.; Dawood, M.H. Monitoring soil enzymes activity before and after animal manure application. Agriculture 2020, 10, 166. [CrossRef]

194. Panuccio, M.R.; Romeo, F.; Mallamaci, C.; Muscolo, A. Digestate application on two different soils: Agricultural benefit and risk. Waste Biomass Valor. 2021, 1-13. [CrossRef]

195. Altieri, M.A.; Nicholls, C.I. Soil fertility management and insect pests: Harmonizing soil and plant health in agroecosystems. Soil Tillage Res. 2003, 72, 203-211. [CrossRef]

196. Borrero, C.; Trillas, M.I.; Ordovás, J.; Tello, J.C.; Avilés, M. Predictive factors for the suppression of Fusarium wilt of tomato in plant growth media. Phytopathology 2004, 94, 1094-1101. [CrossRef]

197. Yatoo, A.M.; Ali, M.N.; Baba, Z.A.; Hassan, B. Sustainable management of diseases and pests in crops by vermicompost and vermicompost tea: A review. Agron. Sustain. Dev. 2021, 41, 1-26. [CrossRef]

198. Manandhar, T.; Yami, K.D. Biological control of foot rot disease of rice using fermented products of compost and vermicompost. Sci. World 2008, 6, 52-57. [CrossRef]

199. Arancon, N.Q.; Galvis, P.A.; Edwards, C.A. Suppression of insect pest populations and damage to plants by vermicomposts. Bioresour. Technol. 2005, 96, 1137-1142. [CrossRef]

200. Kannangara, T.; Utkhede, R.S.; Paul, J.W.; Punja, Z.K. Effects of mesophilic and thermophilic composts on suppression of Fusarium root and stem rot of greenhouse cucumber. Can. J. Microbiol. 2000, 46, 1021-1028. [CrossRef]

201. Szczech, M.; Smolińska, U. Comparison of suppressiveness of vermicomposts produced from animal manures and sewage sludge against Phytophthora nicotianae Breda de Haan var. Nicotianae. J. Phytopathol. 2001, 149, 77-82. [CrossRef]

202. Pane, C.; Spaccini, R.; Piccolo, A.; Scala, F.; Bonanomi, G. Compost amendments enhance peat suppressiveness to Pythium ultimum, Rhizoctonia solani and Sclerotinia minor. Biol. Control 2011, 56, 115-124. [CrossRef]

203. Bonanomi, G.; Lorito, M.; Vinale, F.; Woo, S.L. Organic amendments, beneficial microbes, and soil microbiota: Toward a unified framework for disease suppression. Annu. Rev. Phytopathol. 2018, 56, 1-20. [CrossRef] [PubMed]

204. Tao, C.; Li, R.; Xiong, W.; Shen, Z.; Liu, S.; Wang, B.; Ruan, Y.; Geisen, S.; Shen, Q.; Kowalchuk, G.A. Bio-organic fertilizers stimulate indigenous soil Pseudomonas populations to enhance plant disease suppression. Microbiome 2020, 8, 1-14. [CrossRef]

205. European Commission (EC). Innovating for Sustainable Growth: A Bioeconomy for Europe; European Commission: Brussels, Belgium, 2012.

206. Carrez, D.; Van Leeuwen, P. Bioeconomy: Circular by Nature; The European Files. 2015. Available online: https://biconsortium. eu/sites/biconsortium.eu/files/downloads/European_Files_september2015_38.pdf (accessed on 15 March 2021).

207. Sheridan, K. Making the bioeconomy circular: The biobased industries' next goal? Ind. Biotechnol. 2016, 12, 339-340. [CrossRef] 
208. Stegmann, P.; Londo, M.; Junginger, M. The circular bioeconomy: Its elements and role in European bioeconomy clusters. Resour. Conserv. Recycl. 2020, 6, 100029. [CrossRef]

209. Valve, H.; Ekholm, P.; Luostarinen, S. The Circular Nutrient Economy: Needs and Potentials of Nutrient Recycling. In Handbook of the Circular Economy; Brandão, M., Lazarevic, D., Finnveden, G., Eds.; Edward Elgar Publishing: Cheltenham, UK, 2020; pp. 358-368. [CrossRef] 